\title{
POLEMIK GEGEN DEN HUSSITISCHEN BILDERSTURM IM LICHTE DES TRAKTATES DE SUPERSTITIONIBUS DES JOHANNES VON WÜNSCHELBURG († CA. 1456)
}

Die Person des Johannes von Wünschelburg1, eines aus Schlesien stammenden Prager Magisters der freien Künste, später Professor der Theologie und Bakkalaureus der Dekrete an der Universität in Leipzig und anschließend Prediger in Amberg, ist zum bisherigen Stand der Forschung nicht genügend untersucht worden und befindet sich auch in der deutschen Historiografie nur am Rande des Interesses. Seine wenigen Traktate sind mit Ausnahme kleinerer Schriften weiterhin nur in Handschriften vorhanden oder sind überhaupt nicht bis heute erhalten geblieben ${ }^{2}$.

1 Eine schlesische Kleinstadt bei Glatz, genannt auch: Wunschelberg, Wonschelberg, Wunselburg, Wunschilburg, Wunczschilburg; poln. Radków.

2 Der Artikel entstand im Rahmen eines NPRH-Grant (Nationales Programm für die Entwicklung der Geisteswissenschaften), Nr. 11H 11 003580: Źródła kościelne do dziejów Polski i Rzeczypospolitej am Institut für Geschichte der Polnischen Akademie der Wissenschaften in Warschau (Polska Akademia Nauk w Warszawie, Instytut His- 
Johannes de Wünschelburg (poln. Jan z Radkowa / Radków) war ein deutschsprachiger Schlesier, der ähnlich wie viele seiner schlesischen Landsleute in Prag studierte 3 . Er wurde zwischen 1380 und 1385 wahrscheinlich in Glatz (poln. Kłodzko) geboren, wo seine Familie nach

torii). Siehe auch: A. Herschel, Dr. Wünschelburg, „Serapeum“, 15 (1854), S. 331-333; F. Lauchert, Wünschelburg, in: Algemeine Deutsche Biographie, 44 (1898), S. 320-321; J. Schmidt, Johannes von Wünschelburg, in: Festschrift zu Dr. Franz Volkmers 75 Geburstag, hg. v. A. Franz, (Glatzer Heimatschriften 5, 1921), S. 32-44; D. Kurze, Johann von Wünschelburg, in: Die deutsche Literatur des Mittelalters. Verfasserlexikon, 4 ( $\left.{ }^{2} 1983\right)$, Sp. 818-822 und G. Eis, G. Keil, Nachträge zum Verfasserlexikon, „Studia Neophilologica“, 31 (1959), S. 242, dort jedoch irrige Informationen über ihn; Ch. Stöllinger-Löser, Johann von Wünschelburg, in: Die deutsche Literatur des Mittelalters. Verfasserlexikon. Nachträge und Korrekturen, 11 (2002), Sp. 805-806. Siehe auch: G. Hertel, Abergläubische Gebräuche aus dem Mittellalter, ,Zeitschrift des Vereins für Volkskunde“, 11 (1901), S. 272-279; J. Hansen, Quellen und Untersuchungen zur Geschichte des Hexenwahns und der Hexenverfolgung im Mittelalter, (1901), S. 104, Nr. 21 (Transliteration eines kurzen Textfragments des Traktats nach der Handschrift: Sächsische Landesbibliothek - Staats- und Universitätsbibliothek Dresden (weiter: LSUB Dresden), Sign. Mscr. Dresd. P. 104, f. 1r-38v); H. Ch. Lea, Materials Toward a History of Witchcraft, 1 (1938), S. 131; F. Machilek, Die Schlesier an der Universität Prag vor 1409, „Archiv für Schlesiche Kirchengeschichte“, 32 (1974), S. 100-101; J. Třiška, Životopisný slovník předhusitské pražské univerzity 1348-1409, (Repertorium biographicum universitatis Pragensis praehussiticae 1981), S. 328; K. Bracha, „De ymaginibus sanctorum, quibus utitur ecclesia et cruce" $w$ traktacie De superstitionibus (1444/1445) Jana $z$ Wünschelburga, in: Peregrinationes. Pielgrzymki w kulturze dawnej Europy, hg. v. H. Manikowska, H. Zaremska, (Colloquia Mediaevalia Varsoviensia 2, 1995), S. 64-71; ders., Des Teufels Lug und Trug. Nikolaus Magni von Jauer: Ein Reformtheologe des Spätmittelalters gegen Aberglaube und Götzendienst, (Quellen und Forschungen zur Europäischen Ethnologie 25, 2013), nach Index; D. Harmening, Wörterbuch des Aberglaubens, (2005), S. 239; M. D. Bailey, Fearful Spirits, Reasoned Follies. The Boundaries of Superstition in Late Medieval Europe, (2013), S. 156-157 und nach Index.

3 Zum Thema der in Prag studierenden Schlesier: A. Franz, Mathias von Liegnitz und Nicolaus Stör von Schweidnitz, „Der Katholik. Zeitschrift für katholische Wissenschaft und kirchliche Leben“, 17, 78 (1898), S. 1-25; W. Wostry, Die Schlesier an der Universität Prag vor 1409, „Zeitschrift des Vereins für Geschichte Schlesien“, 66 (1932), S. 1-33; Machilek, Die Schlesier an der Universität Prag, passim; S. Bylina, Wplywy Konrada Waldhausena na ziemiach polskich $w$ drugiej połowie XIV i pierwszej połowie XV wieku, (1966). 
dem Umzug aus Wünschelburg für viele Jahre dem städtischen Patriziat angehörte ${ }^{4} .1348$ trat ein Johannes de Wunschelburk unter den consules in Erscheinung und danach als Hannus von Wunschelburk unter den Ratsherren (rotleute) der Stadt Glatz. Dieser Glatzer Ratsherr starb vor 1354 und hinterließ drei Söhne: Jekil, Hennil und Pecze. Daher kann angenommen werden, dass einer von ihnen sicher der Vater unseres Johannes von Wünschelburg war ${ }^{5}$. In Prag begegnen wir ihm zum ersten Mal im Jahre 1404 als Bakkalaureus der freien Künste und 1406 als Magister Artium. Noch im selben Jahr begann er sein Studium der Rechtswissenschaften (intitulatus in iure) als Student der böhmischen Universitätsnation ${ }^{6}$. Am 16. Juni 1404 wurde er in den Quellen als für die Altäre der Heiligen Laurentius, Vitus, Wenzel, Sigismund, Adalbert und Prokop "patronorum regni Boemie“ zuständiger Altarist in der Pfarrkirche in Habelschwerdt (poln. Bystrzyca Kłodzka) erwähnt ${ }^{7}$. Aber bereits in dem für die Geschichte der Prager Carolina denkwürdigen Jahr $1409^{8}$ teilte er das Schicksal vieler deutscher Professoren und

4 Seine Biografie schildere ich hauptsächlich nach Schmidt, Johannes von Wünschelburg, S. 33-36; Kurze, Johann von Wünschelburg, Sp. 818-819; B. Kusche, „Ego collegiatus" - die Magisterkollegien an der Universität Leipzig von 1409 bis zur Einführung der Reformation 1539. Eine Struktur- und personengeschichtliche Untersuchung, 2 (2009), S. 671-673; A. Herzig, M. Ruchniewicz, Dzieje Ziemi Kłodzkiej, (2006), S. 85, 87.

5 Das älteste Glatzer Stadtbuch, 1324-1412, hg. v. F. Volkmer, W. Hohaus, (Geschichtsquellen der Graffschaft Glatz 4, 1889), S. 11-12, 15.

${ }^{6}$ Liber decanorum facultatis philosophicae universitatis Pragensis ab anno Christi 1367 usque ad annum 1585, 1 (Monumenta Historica Universitatis Carolo-Ferdinandae Pragensis 1, 1830), S. 382, 388; V. Flajšhans, Pražšti theologove kolem r. 1400, „Časopis Českého musea“, 76/77 (1905/1906), S. 23, 31; F. M. Bartoš, Poslání M. Ondřeje Gałky králi Vladislavu Varnenčíkovi, „Věstník Královské české společnosti nauk, třida fil.hist", 1 (1934), S. 7, Anm. 11; Tř́ška, Životopisný slovník, S. 328.

7 Urkunden und Regesten zur Geschichte der Graffschaft Glatz von 1401 bis 1500, hg. v. F. Volkmer, W. Hohaus, (Geschichtsquellen der Graffschaft Glatz, 2, 1888), S. 14.

8 W. W. Tomek, Děje University pražské, 1 (1849), S. 154; F. Seibt, Johannes Hus und der Abzug der deutschen Studenten aus Prag 1409, in: ders., Hussitenstudien. Personen. Ereignisse. Ideen einer frühen Revolution, (Veröffentlichungen des Collegium Carolinum 60, ${ }^{2}$ 1991), S. 1-15; ders., Von Prag bis Rostock. Zur Gründung der Universitäten im 


\section{Studenten und zog mit einer Gruppe Prager Gelehrten nach Leipzig in die dort neu gestiftete Universität ${ }^{9}$. Über seine ersten Jahre an dieser}

Mitteleuropa, in: ders., Mittelalter und Gegenwart. Ausgewählte Aufsätze, hg. v. W. Eberhard, H.-D. Heimann, (1987), S. 197-217 und M. Nodl, Dekret Kutnohorsky, (2010), S. $275-284$.

9 Über die Zahlen der Studenten und Magister besteht zum gegenwärtigen Forschungsstand keine einheitliche Meinung: F. Šmahel, Pražske universitní studentstvo $v$ predrevolučním období 1399-1419. Statistikosociologická studie, (Rozpravy Československé Akademie Věd. Řada Společenských Věd 77, 3, 1967), S. 76-81: 302 Prager Studenten bis zum 1433; ders, The Kuttenberg Decree and the Withdrawal of the German Students from Prague in 1409: A Discussion, in: ders., Die Präger Universität im Mittelalter. Gesammelte Aufsätze, (2007), S. 165-167; E. Bünz, M. Rudersdorf, D. Döring, Geschichte der Universitat Leipzig 1409-2009, 1: Spätes Mittelalter und Frühe Neuzeit 1409-1830/31 (2009), S. 58, nennen eine Zahl von max. 37 Prager Magistern, die 1409 nach Leipzig kamen; E. Bünz, Die Leipziger Universitätsgründung - eine Folge des Kuttenberger Dekret, in: Universitäten, Landesherren und Landeskirchen: Das Kuttenberger Dekret von 1409 im Kontext der Epoche von der Gründung der Karlsuniversität 1348 bis zum Augsburger Religionsfrieden 1555, hg. v. B. Zilynská, (Historia Universitatis Carolinae Pragensis 49, 2, 2010), S. 55-64; nähmlich S. Hoyer, Die Gründung einer Universität in Leipzig 1409, „Leipzig. Aus Vergangenheit und Gegenwart. Beiträge zur Stadtgeschichte“, 3 (1984), S. 88, für die Zeit bis 1433 nennt er die Zahl von insgesamt 227 „Pragern“ in Leipzig; ders., Die Gründung der Leipziger Universität und Probleme ihrer Frühgeschichte, in: Karl-Marx-Universität Leipzig, 1409-1959, (Beiträge zur Universitätsgeschichte 1, 1959), S. 7-8. Zur Geschichte der Universität: F. Zarncke, Die urkundlichen Quellen zur Geschichte der Universität Leipzig in den ersten 150 Jahren ihres Bestehens, „Abhandlungen der philologisch-historischen Klasse der Königlichen Sächsischen Gesellschaft der Wissenschaften“, 3 (1857), S. 509-922; O. Kirn, Die Leipziger Theologische Fakultät in fünf Jahrhunderten, in: Festschrift zur Feier des 500-Jährigen Bestehens der Universität Leipzig, 1 (1909), S. 10, 17; E. Gersdorf, Die Universität Leipzig im ersten Jahre ihres Bestehens, „Bericht an die Mitglieder der Deutschen Gesellschaft zur Erforschung Vaterländischer Sprache und Alterthümer“, (1847), S. 1-61; sowie die grundlegende Universitätsdokumentation: B. Stübel, Urkundenbuch der Universität Leipzig von 1409-1555, (Codex diplomaticus Saxoniae regiae 2, 11, 1879); Die Matrikel der Universität Leipzig, hg. v. G. Erler, 1-2 (Codex diplomaticus Saxoniae regiae 2, 16 und 17, 1895 und 1897) und neue: S. Hoyer, Der Altag in einer Universität de 15. Jahrhunderts. Magister und Scholaren der Alma Mater Lipsienisis, in: Mentalität und Gesellschaft im Mittelalter, hg. v. S. Tanz, (1993), S. 239-240; ders., Die scholastische Universität bis 1480, in: Alma mater Lipsiensis. Geschichte der Karl-Marx-Universität Leipzig 1409-1959, hg. v. L. Rathmann, (1984), S. 9-32; ders., Die Gerichtsbarkeit der Universität Leipzig bis zum Ende des 15. Jahrhunderts, in: Rechtsbücher und Rechtsordnungen 
Universität gibt es jedoch viele Unklarheiten und Kontroversen ${ }^{10}$. In Leipzig immatrikulierte er sich als magister artium und während der Amtszeit des Rektors Helmold Gledenstede von Salzwedel schrieb er sich im Sommersemester 1410 an dritter Stelle unter der polnischen Nation in die Matrikel ein ${ }^{11}$. Im Jahre 1414 erschien er als Magister der freien Künste, Bakkalaureus der Theologie und der Dekrete („,in artibus magister, sacre teologie decretorumque baccalaureus"), und 1425 trat er in einem Brief an Eberhard von Salzburg als „presbyter Pragensis" und „doctor teologie" in Erscheinung, und in den Jahren 1437-1438 anlässlich der Wahl zum Rektor der Leipziger Universität

in Mittelalter und früher Neuzeit, (Schriftenreihe des Sächsischen Staatsministeriums der Justiz 9, 1999), S. 122-142; Kusche, „Ego collegiatus“, passim; K. Krause, Alma mater Lipsiensis. Geschichte der Universität Leipzig von 1409 bis zur Gegenwart, (2003).

${ }^{10}$ Hierbei handelt es sich um die Identifizierung mit einem gewissen Johann Wunschliburg, der unter dem Jahr 1409 im Stiftungsdokument der Universität auftauchte: Die Matrikel der Universität Leipzig, 1, S. 26; Kusche, „Ego collegiatus“, S. 672. Beate Kusche vermutet, dass dies aufgrund des anderen Beinamens („Wunschliburg“, "Wunschelburg") zwei verschiedene Personen sein könnten, es eventuell zu einem Fehler beim Abschreiben des Namens kam oder dass Wünschelburg nach anfänglicher Einschreibung in die Universität die Stadt verließ und sich nach seiner Rückkehr im Jahre 1410 dann erneut in die Matrikel eintrug. Diese Kontroverse ist in der bisherigen Literatur nicht hinreichend entschieden worden und bedarf der weiteren Untersuchung. Eis, Keil, Nachträge zum Verfasserlexikon, S. 242, suggerieren, dass Wünschelburg aus der Diözese Bamberg stammte und in Erfurt wirkte, eine Wiederholung der Suggestion von Hertel, Abergläubische Gebräuche, S. 272 und eine unbegründete Schlussfolgerung der Autoren aus der Fallschilderung der inoffiziellen Verehrung eines alten Holzkreuzes in einem namentlich nicht genannten Ort in der Diözese Bamberg im Traktat: „Reperi enim in quodam opido dyocesis Bamburgensis [in anderen Handschriften: LSUB Dresden, Sign. Mscr. Dresd. P. 104: „Bambergensis“; Biblioteka Uniwersytecka we Wrocławiu [Universitätsbibliothek Breslau] (weiter: BUWr.), Sign. 6098: „Bambergensis“; BUWr., Sign. I. Q. 384: „Bramburgensis“], quandam crucem in quadam statua pendentem quam ibidem plebi sani, cives et rustici, ymmo et mulieres passim appellabant Spiritum Sanctum propter antiquitatem plus enim minimis credunt esse in antiquis imaginibus quam in novis": Alle Zitate weiter nach der Handschrift aus der BUWr., Sign. I. F. 212, f. 245ra-b.

11 „[...] mgr. Iohannes Wunschelburg“: Die Matrikel der Universität Leipzig, 1, S. 32; Kusche, „Ego collegiatus“, S. 672. 
(Iohannes Wunschelburg, Wunselburg) als „artium magister, sacre theologie professor et in iure canonico licentiatus"12. Vom 12. November 1412 (nach dem Tode seines Vorgängers Nikolaus von Wasserburg) bekleidete er - mit Pausen und nicht ohne Schwierigkeiten, bedingt durch Streitigkeiten um Pfründen und den Obedienzkonflikt in der Zeit des Konzils von Pisa - das Amt des Stadtpfarrers im Amberg (in der Diözese Regensburg) ${ }^{13}$. Wünschelburg übte dieses Amt fast ein halbes Jahrhundert lang aus, wobei er sich in Amberg meistens nur im Sommer aufhielt ${ }^{14}$. Außerdem besaß Wünschelburg Pfründen in Görlitz und in Lauban in der Diözese Meißen (21. Mai 1425) ${ }^{15}$. In

12 „[...] ego Iohannes Wunschelburg, artium magister, sacre theologie professor et in iure canonico licentiatus, ipso die sancti Gali electus fui in rectorem alme universitatis studii Lipczensis“: Die Matrikel der Univeristät Leipzig, 1, S. 122; „tenens in suis manibus quandam patentem litteram papiream, a venerabili ac egregio viro domino Iohanne> Wunselburg, sacre theologie professoris iuris canonicique licentiato", Der Urkundenbuch der Universität Leipzig von 1409 bis 1555, Nr. 24, hg. v. B. Stübel, (Codex diplomaticus Saxoniae regiae, 2, 11), (1879), S. 34; Kurze, Johann von Wünschelburg, Sp. 819; Machilek, Die Schlesier an der Universität Prag, S. 101; Kusche, „Ego collegiatus“, S. $672-673$.

13 F. Fuchs, Buchbesitz als Altersvorsorge. Eine Bibliothekstiftung des Johann von Wünschelburg für die Prädikatur bei St. Martin in Amberg im Jahre 1450, in: Wirtschaft - Gesellschaft - Mentalitäten im Mittelalter, hg. v. H.-P. Baum, R. Leng, J. Schneider, (Beiträge zur Wirtschafts- und Sozialgeschichte 107, 2006), S. 686-687, Anm. 14, dort ein Zitat aus dem Dokument mit Vergabe der Prädikatur. Die neueste Edition der Konzilsdokumente: Concilium Pisanum 1409, hg. v. J. Miethke, in: Conciliorum oecumenicorum generaliumque decreta. Editio critica, 2: The General Councils of Latin Christendom, 1: From Constantinople IV to Pavia Siena (869-1424), hg. v. A. Melloni et al., (Corpus Christianorum 2013), S. 471-658.

14 Fuchs, Buchbesitz als Altervorsorge, S. 688.

15 Repertorium Germanicum. Verzeichnis der in den päpstlichen Registern und Kameralakten vorkommenden Personen, Kirchen und Orte des Deutschen Reiches, seiner Diözesen und Territorien vom Beginn des Schismas bis zur Reformation, 4: Verzeichnis der in den Registern und Kameralakten Martins V. vorkommenden Personen, Kirchen und Orte des Deutschen Reiches, seiner Diözesen und Territorien, 1417-1431, hg. v. K. A. Fink, 3 (1957), Sp. 5448; Tříška, Životopisný slovník, S. 328; Fuchs, Buchbesitz als Altervorsorge, S. 690. 
den darauffolgenden Jahren trat er als Mitglied des collegium minus in Leipzig in Erscheinung (etwa 1431 oder 1435-1438) ${ }^{16}$. Auch über das Datum seines Todes besteht Unklarheit. In der letzten Erwähnung (1456) ist von ihm weiterhin als Prediger in der Kirche St. Martin in Amberg die Rede („predicator opidi Amberg ") ${ }^{17}$.

In der bisherigen Literatur ist Wünschelburg am bekanntesten als der Autor der sog. Gamaleon-Predigt (Visio Gamaleonis, Prophetia de ultimis temporibus), einer am 24. August 1439 von der Kanzel in Amberg herab verkündeten prophetischen Vision über die Zukunft der Kirche und der Welt, in welcher er auf eine andere Vision des italienischen Minoriten Telesforus von Cosenza (de Cusentia) von etwa 1386 reagierte (Vaticinium de ultime temporibus, De causis, de statu, de cognitione ac fine praesentis scismatis et tribulationum futurarum), worin vorausgesagt wurde, der französische König werde dem deutschen König die kaiserliche Macht entreißen ${ }^{18}$. In Wünschelburgs Vision sollten u.a. die

16 Schmidt, Johannes von Wünschelburg, Sp. 35 war der Ansicht, dass Wünschelburg bis 1427 aus den Universitätsdokumenten verschwand, um in den Jahren 1427-1438 im Zusammenhang mit der Notiz auf der von F. Zarncke, Die urkundliche Quellen zur Geschichte der Universität Leipzig in der ersten 150 Jahren ihres Bestehens, S. 764: Verzeichniss der Collegiaten redigierten Mitgliederliste dieses Collegiums als Mitglied des collegium minus erneut in Erscheinung zu treten: „1427-1438 B. Joh. Wünschelburg in Bavariam discessit, ibique miraculis factis fortiter se opposuit", und eine Verifkation von Kusche, „Ego collegiatus“, S. 671-672, 854, 861. Fuchs, Buchbesitz als Altervorsorge, S. 690 nimmt an, dass diese Eintragung auf die verschollene Arbeit De signis et miraculis falsis zurück geht.

17 „Scripsit Stephanus de Egling tunc temporis ex Altingen capellanus sancti spiritus domini Johannis Wunschilburg predicatoris opidi Amberg": die Handschrift in der Bayerischen Staatsbibliothek in München, Sign. 23800, f. 241 r. Zit. nach: K. Halm, G. von Laubmann, W. Meyer, Catalogus codicum latinorum Bibliothecae Regiae Monacensis, 2, 4: Codices num. 21406-27268 complectens, (1881), S. 95; Schmidt, Johannes von Wünschelburg, Sp. 35-36; Kurze, Johann von Wünschelburg, Sp. 819. Einer seiner Nachfolger in der Prädikatur in Amberg war der Theologe Johann Spieß (gest. 1488): Fuchs, Buchbesitz, S. 692, Anm. 31.

18 Ch. Stöllinger-Löser, Telesforus von Cosenza, in: Die deutsche Literatur des Mittelalters. Verfasserlexikon, 9 (1995), Sp. 679-682; E. Donckel, Studien über die Pro- 
Dynastie der Jagiellonen und der polnisch-litauische Staat (Witold und Władysław II Jagiełło) eine große Rolle für die (Wieder)Instandsetzung der Welt spielen. In einer anderen deutschen Version der Prophezeiung Practica maister Hannsens von Wunschlwurg, die keine Übersetzung der lateinischen Visio Gamaleonis ist, entwickelte er nämlich die Vision, die Jagiellonen würden den Türken Konstantinopel abnehmen und für den katholischen Glauben zurückgewinnen und auch Prag von den Hussiten befreien. „Das Haupt der Welt wird sterben, aber des Menschen Sohn und der Adler mit Kindern werden bleiben: erst dann wird Frieden auf Erden sein"19. Wünschelburg hinterließ mindestens zwei nicht völlig identifizierte und bisher unerforschte Predigtsammlungen:

phezeiung des Fr. Telesforus von Cosienza, O.F.M. 1365-1386, „Archivum Franciscanum Historicum", 26 (1933), S. 29-104; 282-314.

19 „Darnach vber vier jar werdent gross streit in der werlt wirt zuerstört. Das hawbt der werlt wirt sterbenn. Aber des menschenn sun vnd der Adler werdent peleiben. [...] Die lilgen das ist der kunig von Vngern. Der Leo ist Beheimer Lanndt. Die dorn sein die Hussenn. Des menschen sun ist genant Witold. Die tier das sein die vngelaubigenn. Der Adler das ist der kunig von Polen. Die kinder das ist sein Volkch. Das hawbt der werlt das ist der pabst": Practica maister Hannsens von Wunschlwurg, hg. v. F. Lauchert, Materialien zur Geschichte der Kaiserprophetie im Mittelalter, 1: Die dem Johannes Wünschelburg zugeschriebene Prophezeiung, „Historisches Jahrbuch der Görres-Gesellschaft", 4 (1898), S. 850-851; E. Hermann, Veniet aquila de cuius Molatu delebitur Leo. Zur Gamaleon-Predigt des Johann von Wünschelburg, in: Festiva lanx. Studien zum mittelalterlichen Geistesleben Johannes Spörl dargebracht aus Anlass seines sechzigsten Geburtstages, hg. v. K. Schnith, (1966), S. 95-117 (lateinsche und deutsche Edition: S. 114-117, hier S. 116). Siehe: J. Fijałek, Mistrz Jakub z Paradyża i uniwersytet krakowski w okresie soboru bazylejskiego, 1 (1900), S. 207-208; A. F. Grabski, Polska w opiniach Europy Zachodniej, (1968), S. 98-99; E. Potkowski, Książka rękopiśmienna w kulturze Polski średniowiecznej, (1984), S. 45. Stöllinger-Löser, Johann von Wünschelburg, Sp. 806 korrigierte, dass die deutsche Practica maister Hannsens von Wunschlwurg entgegen früheren Vermutungen keine Übersetzung der lateinischen Visio Gamaleonis ist und keine gemeinsame Grundlage mit Wünschelburgs Predigt besitzt. Ähnlich hat auch eine andere deutsche "Gamaleon-Prophetie" (Neun Texte zur Geschichte der religiösen Aufklärung in Deutschland während der 14. und 15. Jahrhunderts, hg. v. A. Reifferscheid, in: Festschrift der Universität Greifswald, (1905), S. 47-50) nichts mit der Autorschaft Wünschelburgs gemeinsam. 
Discipulum de sanctis ac officiarium de sanctis sowie einen Zyklus mit Predigten für die Fastenzeit Sermones per Quadragesimas ${ }^{20}$.

Das umfangreichste und, wie es scheint, interessanteste Werk Wünschelburgs ist jedoch der Tractatus de superstitionibus. Die charakteristische Ausrichtung auf die Kritik an erfundenen Wundern, verdächtiger Verehrung heiliger Bilder und an falschen Wallfahrten erinnert an einen früheren, heute leider nicht mehr erhaltenen, von Wünschelburg redigierten Traktat De signis et miraculis falsis, von dem wir nur aus indirekten Berichten aus dem 16. Jahrhundert wissen ${ }^{21}$. Dieser verlorene Traktat des Leipziger Theologen bildete einen der in jener Zeit zahlreichen Auftritte kirchlicher Schriftsteller gegen Wallfahrten zur gnadenspendenden Wunderbluthostie in Wilsnack ${ }^{22}$. Der

20 Erhalten in den Handschriften in: München Bayerische Staatsbibliothek, Sign. Clm 9730, f. 161r-236v und Universitätsbibliothek Würzburg, Sign. M. ch. f. 137, f. 99va-131rb. Siehe: K. Halm, G. von Laubmann, W. Meyer, Catalogus codicum latinorum Bibliothecae Regiae Monacensis, 2, 1: Codices num. 8101-10930 complectens (1874), S. 121-122; Die Handschriften der Universitätsbibliothek Würzburg, 2: Die Handschriften aus benediktinischen Provenienzen, bearb. v. H. Thurn, 1 (1973), S. 132-133 und Fuchs, Buchbesitz, S. 685, Anm. 10; Repertorium der lateinischen Sermones des Mittelalters für die Zeit von 1350-1500, nach der Vorarbeit v. J. B. Schneyer hg. v. L. Hödl, W. Knoch, (CD ROM 2001): notiert nicht. Siehe auch: Sermo defunctorum magistri Johanni Wunschelburgensis: BUWr., Sign. I. Q. 58, f. 110vb-113ra.

21 Erwähnt im Chronikwerk Georgii Fabricii Chemnicensis Rerum Misnicarum libri VI, Lib. 2, Drucker: Cvrante Ernesto Voegelino, (1569), S. 150 (das Jahr 1444). Wünschelburgs Traktat De signis et miraculis falsis befand sich darüber hinaus ab 1557 auf der Liste Index librorum prohibitorum in Rom: Thesaurus de la littérature interdite au XVI siècle, Auteurs, ouvrages, éditions, hg. v. J. M. de Bujanda, (Index des livres interdits 10, 1996), S. 413. In einem von ihnen wurde u.a. notiert, dass er „recenset in eo aliquot fallacias auarorum sacerdotum, ut De imagine Christii sudante. De rubigine in manubrio crystallino pro sanguine Christi, Cracouiae adorato. De resina ex lignea imagine defluente, et eodem modo pro Christi sanguine habita. De sacerdote Boemico, qui suo sanguine ad decipiendum populum tinxit ostiam. De ementito sanguine Christi in Vuelsnag oppido Saxoniae, cuius causa eum librum scripsit", Epitome bibliothecae Conradi Gesneri, apud Christophorum Froschouerum, mense Martio, anno 1555 Content, Drucker: Tigvuri (1555), f. 112va-b und Kurze, Johann von Wünschelburg, Sp. 820; Schmidt, Johannes von Wünschelburg, S. 36.

22 Ausführlicher siehe: K. Bracha, Zwischen miracula, mirabilia und mira. Die 
präsentierte Traktat De superstitionibus stellt, wie es scheint, eine neue, deutlich erweiterte Version der verlorengegangenen Abhandlung über die falschen Wunder bzw. ihre Ergänzung dar, auch wenn Wilsnack darin nicht erwähnt wird ${ }^{23}$.

Der Traktat des Leipziger Theologen ist eines der zahlreichen Beispiele (wenn auch ein untypische) Aberglaubensliteratur des Spätmittelalters. Er repräsentiert - nicht ohne den Einfluss der Atmosphäre und der diesbezüglichen Errungenschaften der Prager Akademie - die Haltung kirchlicher reformatorischer Kreise zu den von der Kirche nicht gebilligten und bekämpften Erscheinungsformen populärer Devotion, welche von den Theologen allgemein als superstitiones bezeichnet wurden, sowie zu den unterschiedlichen Irrtümern und Missbräuchen im Heiligenkult.

Die gelehrte Abhandlung des hochgebildeten Leipziger Theologen gliedert sich in sechs umfangreiche, fast gleich große Quaestionen:

[1] De superstitiositate verborum

[2] De superstitiositate temporis

[3] De ymaginibus et signis eorum

[4] De ymaginibus sanctorum, quibus utitur Ecclesia et cruce crucifixi

[5] De miraculis circa ymagines

[6] De miraculis Christi24.

Wallfahrten nach Wilsnack im Urteil Jakobs von Paradies, in: Die Wilsnackfahrt. Ein Wallfahrts- und Kommunikationszentrum Nord- und Mitteleuropas im Spätmittelalter, hg. v. F. Escher, H. Kühne, (Europäische Wallfahrtsstudien 2, 2006), S. 165-177; H. Boockmann, Der Streit um das Wilsnacker Blut. Zur Situation des deutschen Klerus in der Mitte des 15. Jahrhunderts, „Zeitschrift für historische Forschung“" 9 (1982), S. 385-408; Wunder - Wallfahrt - Widersacher. Die Wilsnackfahrt, hg. v. H. Kühne, A.-K. Ziesak, (2005); V. Honemann, Wilsnacker Wunderblut', in: Die deutsche Literatur des Mittelalters. Verfasserlexikon, 10 (1999), Sp. 1171-1178, dort weitere Literaturangaben zur Thematik. Es ist jedoch nicht ausgeschlossen, dass Wünschelburgs Traktat über das Wunder in Wilsnack viel früher entstanden ist, vgl. Kurze, Johann von Wünschelburg, Sp. 820.

23 Schmidt, Johannes von Wünschelburg, S. 37.

24 Quaestion 4 des Traktats bildete bereits den Gegenstand einer gesonderten 
Die theologische Darlegung der abergläubischen Inhalte und Irrtümer im Kult hat bisher weder eine umfassend kritische Bearbeitung noch eine gedruckte Edition erfahren. Sie existiert bis heute ausschließlich in fünf erhaltenen Handschriften aus dem 15. Jahrhundert. Eine Manuskriptkopie ging im letzten Krieg verloren ${ }^{25}$. Der Zirkulationsbereich der Handschriften und ihrer Provenienz ist auf das geschlossene Nachbarschaftsgebiet Schlesiens und der sich anschließenden Gebiete Ostdeutschlands (Sachsen, Thüringen) beschränkt. All dies zeugt von einer eher nur lokalen Reichweite der Popularität des Tractatus de superstitionibus. Bemerkenswert ist, dass sich zwei Handschriften ${ }^{26} \mathrm{im}$ Besitz von Regularkanonikern vom hl. Augustinus aus Sagan sowie aus Grünberg befanden, einem bekannten Zentrum reformatorischer Ideen, das über eine reichhaltige Bibliothek verfügte ${ }^{27}$. Nur eine Handschrift zeugt, was überraschen mag, von ihrer Herkunft aus der Leipziger Universitä ${ }^{28}$. Die älteste Handschrift aus der Universitätsbibliothek Breslau ${ }^{29}$ aus dem Jahre 1452 (Filigrane: 1430, 1437) bildet

Analyse des Autors: Bracha, „De ymaginibus sanctorum, quibus utitur ecclesia et cruce“, S. 64-71. Siehe auch weiter unten im Annex.

25 Siehe unten im Annex.

26 BUWr., Sign. I Q. 384 und Sign. I. F. 274.

27 F. Machilek, Ludolf von Sagan und seine Stellung in der Auseinandersetzung um Konziliarismus und Hussitismus, (Wissenschaftliche Materialien und Beiträge zur Geschichte und Landeskunde der böhmischen Länder 8, 1967).

28 BUWr., Sign. 6098/Mil. II. 46. Zum Thema der Leipziger Handschriften und des Forschungsstandes zur Sammlung: J. Wróbel, Aus der aktuellen Forschung über die mittelalterlichen Handschriften der Universitätsbibliothek in Leipzig, „Studia Mediewistyczne", 27, 1 (1990), S. 81-88 und R. Helssig, Die lateinischen und deutschen Handschriften der Universitätsbibliothek Leipzig, 1: Die theologischen Handschriften, 1: (Ms 1-500), (unveränderter Nachdruck der Auflage von von 1926, 1995); P. Burkhart, Die lateinischen und deutschen Handschriften der Universitätsbibliothek Leipzig, 2, 5: Die lat. und dt. Hs.. Die theologischen Handschriften, 1: (Ms 501-625), (1999); R. Helssig, Die lateinischen und deutschen Handschriften der Universitätsbibliothek Leipzig, 3: Die juristischen Handschriften, (unveränderter Nachdruck der Auflage von 1905, 1996).

29 BUWr., Sign. I F. 212, f. 228ra-258vb. 
die Quellengrundlage für die in Vorbereitung befindliche Edition des Traktats $^{30}$.

Das Redaktionsdatum des Traktats ist unbekannt. Der Autor erwähnt im Traktat das Konzil in Basel (Basel - Ferrara - Florenz - Rom in den Jahren 1431-1449) ${ }^{31}$, sowie die Irrtümer von Wyclif und Hus in Bezug auf den Bilderkult. Man kann davon zeugen, dass der Text um die Mitte des 15. Jahrhunderts entstanden ist und die Datierungen der zwischen 1452 und 1466 (in ihrer überwiegenden Mehrheit in den fünfziger Jahren des 15. Jahrhunderts) abgeschriebenen Handschriften bestätigen diesen Befund ${ }^{32}$. Auf dem Konzil in Basel befasste man sich mit der böhmischen Frage nach der Tagesordnung des vorher am 18. Mai

30 K. Jażdżewski, Catalogus manu scriptorum codicum medii aevi latinorum signa 180-260 comprehendens, (1982), S. 228-232. Der Codex enthält eine typische Sammlung von Schriften mit pastoraler Bestimmung, und zwar der Reihe nach: Expositio symboli apostolorum des Johannes von Marienwerder (Johannes von Kwidzyn), Tractatus de Sacramento Eucharistie des Ps. Bonaventura, De instructione sacerdotis des Piotr von Syców, Themata sermonum de passione Christi des Johann Gerson, De pollutione diurna des Johann Kannemann, De decem praeceptis des Matthäus von Krakau, De contractibus und De modo audiendi confessionum des Heinrich von Hessen.

31 Darauf hat schon Anton Herschel aufmerksam gemacht: Herschel, Dr. Wünschelburg, S. 332.

32 „Sed in Novo Testamento Deus factus est homo, potest in sua ymagine corporali adorari, huic autem traditioni et usui ecclesie de ymaginibus contradixerunt heretici hussite et Wicleff et maxime Trinitatis ymagini fulminat anathema, ubi pater speciem viri habet senis, filius iunioris et Spiritus Sanctus columbe tipum habet dicentes, quomodo spiritualem et in circumscriptibilem divine essentie (f. 241va) quam cogitare non possumus sensibili forma depingere curamuS. Et pater inquit homo non erat nec est visus ut homo, qua ergo audacia audent sibi ymaginem hominis quam minime recognovit. Huic errori Wicleff et hussitarum de hac Trinitate volens obviare Sacrosanctum concilium Basilense": BUWr., Sign. I F. 212, f. 241rb-241va. Siehe weiter unten im Annex. Das Jahr 1444/1445 wird als Datum der Redaktion des Traktats angenommen von Schmidt, Johannes von Wünschelburg, Sp. 37 und Kurze, Johann von Wünschelburg, Sp. 820 und auch Hansen, Quellen und Untersuchungen, S. 104: 1440 Jh., und Hertel, Abergläubische Gebräuche aus dem Mittellalter, S. 272: die siebziger Jahre des 15. Jh., was im Zusammenhang mit den Lebensjahren des Autors nicht in Frage kommt und ein von diesem Autor angenommenes Datum der Anfertigung der Handschrift darstellt. 
1432 in Eger (Cheb) geschlossenen Elfpunkteabkommens ${ }^{33}$. Die erste Runde der Diskussionen mit der hussitischen Abordnung fand zwischen dem 4. Januar und dem 14. April 1433 statt, die zweite vom 2. August bis zum 11. September. Schließliche wurde die Einigung in Form der sog. „Basler Kompaktate“ am 5. Juli 1436 in Iglau unterzeichnet ${ }^{34}$. Auf den Beratungen wurde über das Thema der böhmischen Ikonophobie debattiert ${ }^{35}$. Und 1439 wurde in Florenz das Dogma von der Heiligen Dreifaltigkeit (in der Bulle Laetentur caeli) abgesprochen ${ }^{36}$.

33 Erwähnt von I. Stojkovič, Johannis de Ragusio Tractatus, quomodo Bohemi reducti sunt ad unitatem ecclesiae, hg. v. F. Palacký, (Monumenta Conciliorum Generalium seculi decimi quinti. Concilium Basileense. Scriptorum 1, 1857), S. 219-220. Siehe: A. Molnár, Chebský soudce, in: Soudce smluvený v Chebu. Sborník př́spèvků přednesenych na symposium k 500. výročí, květen 1982 Cheb, (1984), S. 5-40; J. Nikodem, Od Brna do Iglawy. Husyckie misje dyplomatyczne z lat 1419-1436, „Kwartalnik Historyczny", 121, 1 (2014), S. 123; F. Šmahel, Husitská revoluce, 3: Kronika válečných let, (1996), S. 231-252, 396, Anm. 479; S. Bylina, Podróż husytów do Bazylei, (2013), S. 40.

34 Ein Überblick über die Quellen und Forschungen siehe: M. Wesche, Concilium Basileense, abrufbar im Internet: http://www.repfont.badw.de/Concilium\%20 Basileense.pdf (31.12.2015), S. 22 und J. Kejř, Česká otázka na Basilejském koncilu, „Husitský Tábor“, 8 (1985), S. 107-132; A. Krchňák, Čechové na Basilejském sněmu, (1997); F. Šmahel, Basilejská kompaktáta, jejich zpísemněnín a ratifikace, „Studia Mediaevalia Bohemica“, 1, 2 (2009), S. 187-229; ders., Basilejská kompaktáta. Příběh deseti listin, (2011), S. 27-33; ders., Husitská revoluce, 3, S. 259-319; Bylina, Podróż husytów do Bazylei, S. 13-42; ders., Rewolucja husycka, 2: Czas chwały i czas zmierzchu, (2015), S. 74-84; Nikodem, Od Brna do Iglawy, S. 122-131.

35 Die ikonoklastischen Diskussionen illustrieren die Konzilstraktate und Diarien von I. Stojkovič, Johannis de Ragusio Tractatus, S. 269, 273; ders., Initium et prosecutio Basiliensis concili, hg. v. F. Palacký, (Monumenta conciliorum generalium seculi decimi quinti. Concilium Basileense 1, 1857), S. 82; Peter von Žatca: Petri Zatecensis Liber diurnus de gestis Bohemorum in concilio Basileensi, hg. v. F. Palacký, (Monumenta conciliorum generalium seculi decimi quinti. Concilium Basileense 1, 1857), S. 294-295, 298, 308, 343; Gilles Charlier: Aegidi Carlerii Liber de legationibus Basiliensis pro reductione Bohemorum, hg. v. E. Birk, (Monumenta conciliorum generalium seculi decimi quinti. Concilium Basileense 1, 1857), S. 603.

36 Dokumenty soborów powszechnych, 3: Konstancja Bazylea - Ferrara - Florencja - Rzym (1414-1445), hg. v. A. Baron, H. Pietras, (2004), Sesja 6, 10a-b, S. 468-469; B. Sesboüé, J. Wolinski, Bóg zbawienia, in: Historia dogmatów, hg. v. B. Sesboüé, 1 (1999), S. 295-297. 
In der ganz besonders dieser Thematik gewidmeten Quaestion 3 des Traktats De ymaginibus et signis eorum sowie in der darauffolgenden, ihre Entfaltung bildenenden Quaestion 4 De ymaginibus sanctorum, quibus utitur Ecclesia et cruce crucifixi nahm Wünschelburg Bezug auf die schon in vorhussitischer Zeit in Böhmen geführte Diskussion, die den als Götzendienst angesehenen Bilderkult in Frage stellte ${ }^{37}$. Im Kontext der Debatte gegen den Ikonoklasmus berief sich Wünschelburg u.a. auf die in dieser Problematik oft zitierten Werke des Johannes Damascenus De fide orthodoxa und De imaginibus oratio ${ }^{38}$. Gegen die alte fromme Tradition der Kirche hatten sich damals Matthias von Janov (Matěj z Janova), Nikolaus von Dresden (Mikuláš z Dráždan), Jakobellus von Mies (Jakoubek ze Stř́ibra) sowie Wenzel Koranda (Václav Koranda), Johann von Seelau (Jan Želivský), Matthias Jakobi von Kapliz (Jakob Matějův von Kaplic), Hieronymus von Prag, Johann von Př́bram sowie die taboritischen Chiliasten gewandt ${ }^{39}$. Der Ersterwähnte musste schon 1389 wegen seiner Auftritte gegen den Heiligenkult und die Bilderverehrung auf der Synode seine Ansichten widerrufen ${ }^{40}$. Der Zweitgenannte fügte

37 BUWr., Sign. I F. 212, f. 239rb-245ra; 245ra-248rb. Siehe unten: Annex.

38 BUWr., Sign. I F. 212, f. 241ra-b, 244vb, 246vb. S. auch Johannes Damascenus, De fide orthodoxa, hg. v. J.-P. Migne, (Patrologia Graeca 94, 1867), col. 790-1228; Jean Damascène, La Foi orthodoxe, 2: 45-100, hg. v. B. Kotter, (Sources chretiennes 540, 2011), c. 89, IV, 16: „Sur les images“, S. 237-243; ders., Contra imaginum calumniatores I-III, in: S. Joannis Damasceni De imaginibus oratio I-III. Adversus eos, qui sacras imagines abiiciunt, hg. v. J.-P. Migne, (Patrologia Graeca 94, 1867), col. 1231-1420. Siehe O. Halama, Otázka svatých v české reformaci, (2002), S. 95-96.

39 Eine kurze Geschichte des bömischen Bilderstreits bis zum 16. Jahrundert bei O. Halama, Otázka svatých, S. 9-94 (S. 155-219: Edition der 5 Texten, u.a. von Johann von Př́ibram Professio fidei); M. Bartlová, Pravda zvítězila. Výtvarné umění a husitství 1380-1490, (2015), S. 53-164.

40 Matthiae de Janov dicti magister Parisiensis Regulae veteris et novi testamenti, Liber III: Tractatus de Anticristo. Accedit tractatus magistrorum Parisiensium de periculis novissiorum temporum rec non Milicii libellus de antichristo (weiter: Matthiae de Janov, Liber III), hg. v. V. Kybal, (1911), S. 36-40 (tř. 5, dist. 5, c. 10): „De operacione Sathane in Antichristo per suos"; Matthiae de Janov dicti Magistri Parisiensis Regularum veteris et novi testamenti, Liber V: De corpore Christi (weiter: Matthiae de Janov, Liber V), 
seinem umfangreichen, nicht vollständig erhaltenen Traktat De reliquis et veneratione sanctorum den Teil De imaginibus bei ${ }^{41}$. Und Jakobellus von Mies war der Verfasser zweier Abhandlungen zu diesem Thema: Posicio de imaginibus et adoracione illarum (Tractatulus de imaginibus) sowie Epistola de censu fumalium, de cultu imaginum et censibus quibus dotata est ecclesia (De fumalibus) ${ }^{42}$. Zu den ersten gewaltsamen Kon-

hg. v. J. Nechutová, H. Krmíčková, (Veröffentlichungen des Collegium Carolinum 69, 6 1993), S. 81-111 (dist. 6a, c. 1-4): „De ymaginibus in templis vel statuis“; Pražské synody a koncily předhusitské doby, hg. v. J. V. Polc, Z. Hlediková, (2002), S. 245-247. Siehe auch: V. Kybal, M. Matej z Janova. Jeho život, spisy a učeni, (1905), S. 131-135; V. Herold, M. Mraz, Zur Geschichte des tschechischen philosophischen Denkens der vorhussitischen Zeit (Stand, Probleme und Perspektiven der Forschung), „Mediaevalia Philosophica Polonorum“, 24 (1979), S. 44; J. Hrdina, Ośrodki pielgrzymkowe w średniowiecznych Czechach. Problematyka i realia, in: Peregrinationes $w$ kulturze dawnej Europy, hg. v. H. Manikowska, H. Zaremska, (Colloquia Mediaevalia Varsoviensia 2, 1995), S. 252-260; S. Bylina, Z problematyki kontaktów Macieja z Janowa ze Ślaskiem w drugiej połowie XIV wieku, „Śląski Kwartalnik Historyczny Sobótka“, 19, 3-4 (1964), S. 328-335. J. Royt, Die Hussiten und ihr Verhältnis zur Kunst, in: Jan Hus - Zwischen Zeiten, Völkern, Konfessionen, hg. v. F. Seibt, Z. Dittrich, (Veröffentlichungen des Collegium Carolinum 85, 1997), S. 314-315 zählt diese Gruppe böhmischer Denker zu den eigentlichen Ikonoklasten, neben den Kritikern der Bildermissbräuche im Kult im abergläubischen Kontext sowie dem gewöhnlichen Pöbel, der die Kirchen aus Gewinnsucht ausraubte und plünderte; O. Halama, Otázka svatých v české reformaci, S. 12-13; Bartlová, Die Bildersturm, S. 36; dies., Pravda zvitězila, S. 62.

41 Edition: J. Nechutová, Nicolai de Dresda „De imaginibus“, „Sborník prací Filozofické Fakulty Brněnské univerzity. E: Řada archeologicko-klasická“", 19, 15 (1970), S. 211-240; dies., Traktát Mikuláše z Dráždan "De imaginibus" a jeho vztah k Matěji z Janova, „Sborník prací Filozofické Fakulty Brněnské univerzity. E: Řada archeologicko-klasická", 13, 9 (1964), S. 149-162; dies., Traktát „De ymaginibus", prípisovaný Petru Paynovi (Pražský univerzitní kodex IX E 10, ff. 210v - 214r), „Husitský Tabor“, 9 (1987), S. 325-334; dies., Polemika Štěpána s Dolan z husitskou ikonofobií, in: Hussitism - Reformation - Reinassance, hg. v. J. Pánek, M. Polívka, N. Rejchrtová, (1994), S. 391-399.

42 Liste der Handschriften und Abschriften: P. Spunar, Repertorium auctorum Bohemorum provectum idearum post Universitatem Pragensem conditam illustrans, 1 (Studia Copernicana 25, 1985), S. 236-237, Nr. 639; S. 241, Nr. 655; Hg. v. J. Bělohlávková, Jakoubek ze Stř́ibra a Petr Payne: O obrazech, (1987), S. 44-83; J. Nechutová, Filius patri mortuo statuam fecit. Bájný antický př́běh v české reformaci, in: Jakoubek ze 
flikten auf diesem Hintergrund kam es gleich nach dem Tode Wenzels IV. (im Jahre 1419), als eine revolutionäre Menge einige Klöster und Kirchen zu verwüsten begann ${ }^{43}$. Sicher ist, dass in der Genese beider Traktate der Einfluss Prager reformatorischer Kreise gar nicht hoch genug eingeschätzt werden kann, wo die Frage des Bilderkultes seit langem diskutiert und von den Hussiten in Frage gestellt wurde ${ }^{44}$. Dies

Stříbra. Texty a jejich působení, hg. v. O. Halama, P. Soukup, (2006), S. 91-93, Anm. 18, 20; J. Bělohlávková, Die Ansichten über Bilder im Werk tschechischen Reformprediger, „Studie o rukopisech“, 29 (1992), S. 53-64; O. Halama, Otázka svatých, S. 13-18, 116-121; K. Sedlačkova, Jakoubek ze Střibra a tzv. tynske kázání z 31. ledna 1417. Názory předhusitských a husitských 'reformatorü' na obrazy, „Opuscula historiae artium. Sborník prací filosofické fakulty brněnské university“, F, 48 (2004), S. 7-43

43 K. Stejskal, Ikonoklasmus českeho středověku a jeho limity, „Uměni“, 48 (2000), S. 206-217; ders., Ikonoklasmus a naš pamatkovy fond, „Husitsky Tabor“, 13 (2002), S. 71-110; M. Bartlová, Der Bildersturm der böhmischen Hussiten: Ein neuer Blick auf eine radikale mittelalterliche Geste, „Wiener Jahrbuch für Kunstgeschichte“, 59 (2010), S. 33, 39; dies., Pravda zvítězila, S. 63, 89-98. S. Bylina, Rewolucja husycka. Przedświt i pierwsze lata, (2011), S. 227-228, dort ein Bericht aus der Chronik des Johann von Pibrans (Př́bramě). Siehe auch den Bericht von Johannes de Ragusio (Ivan Stojkovič), Initium et prosecutio Basiliensis concilii, hg. v. F. Palacký, (Monumenta conciliorum generalium seculi decimi quinti. Concilium Basileense 1, 1857), S. 82. Von gewissen Spuren der Ikonophobie, wenn auch mit unsicherem Hintergrund, blieben auch die polnischen Gebiete nicht verschont, da wir in den Konsistorialquellen lesen, dass Paweł Lubowski und Piotr Mączka von Łomża angeklagt wurden, weil: „subvertentes ymagines in altari pedibus, sursum dorso verterunt et facie ad parietem, more hereticorum": Acta capitulorum nec non iudiciorum ecclesiasticorum selecta, hg. v. B. Ulanowski, 2 (1902), Nr. 1215; E. Maleczyńska, Ruch husycki w Czechach i w Polsce, (1959), S. 517.

44 Siehe vor allem die gesammelten Artikel in „Husitský Tábor“, 8 (1985): J. Krása, Husitské obrazoborectví: poznámky k jeho studiu, S.9-17; K. Stejskal, Funkce obrazu v husitství, S. 19-28; J. Nechutová, Prameny predhusitské a husitské ikonofóbie, S. 29-38; J. Chlíbec, K vývoji názorů Jana Rokycany na umělecké dílo, ebenda, S. 39-57; N. Rejchrtová, Obrazoborecké tendence utrakvistické mentality jagellonského období a jejich dosah, S. 59-68. S. auch Royt, Die Hussiten, passim; Nechutová, Polemika Štěpána $z$ Dolan s husitskou ikonofobií, S. 391 u.a.; J. Dębicki, Ein Beitrag zur Bildertheologie der vorhussitischen und hussitischen Zeiten in Böhmen, „Umění, 30, 6 (1992), S. 415-422; ders., Ideowe przesłanki obrazoburstwa $w$ Czechach $w$ czasach przedhusyckich i husyckich a teologia obrazu w okresie wczesnej reformacji, in: Sztuka i dialog wyznań w XVI i XVI wieku, hg. v. J. Harasimowicz, (2000), S. 77-87; K. Stejskal, Ikonoklasmus českého 
schließt nicht aus, dass bei der Entstehung beider Traktate auch Kreise des Diözesanklerus eine Rolle gespielt haben könnten. Diesbezüglich wäre ein Gesetz der Breslauer Synode aus dem Jahre 1466 zu nennen, das die Propagierung Verdacht erregender Kulte durch die Pfarrgeistlichkeit verbot ${ }^{45}$.

Viele damalige kirchliche Autoren reagierten auf die hussitische Frage und neigten daher zur Polemik, aber im Falle Wünschelburgs stellt sich noch die Frage nach dem Einfluss der Situation in der Heimatstadt des Leipziger Theologen oder umfassender in Schlesien überhaupt ${ }^{46}$. An Wünschelburg waren das hussitische Phänomen und der offene Religionskrieg in der gesamten Grafschaft Glatz nicht spurlos vorübergegangen. Nach dem Erlöschen des Abkommens der Glatzer

středověku a jeho limity, „Umění“, 48 (2000), S. 206-217; ders., Pokus o zničení obrazu $v$ Betlémské kapli v Praze roku 1412. Př́spèvek $k$ dějinám ikonoklasmu v Čechách, in: Septuaginta Paulo Spunar oblata (70+2), (2000), S. 399-400; ders., Ještě k ikonoklasmu $v$ Čechách, „Listy Filologické“, 122 (1999), S. 194-196; Bilder, in: Theologische Realenzyklopädie, 6 (1980), S. 515-568 und letztens von Perspektiven der Kunstgeschichte: M. Bartlová, Understanding Hussite Iconoclasm, „Filosofický časopis AV ČR“, Suppl. 1 (2009), S. 115-126; dies., Der Bildersturm der böhmischen Hussiten: Ein neuer Blick auf eine radikale mittelalterliche Geste, S. 27-48; dies., Obraz jako náboženský problém. Husitské obrazoborectví, in: Umění české reformace (1380-1620), hg. v. K. Horníčková, M. Šroněk, (2011), S. 41-204; dies., Skutečná přitomnost: středověký obraz mezi ikonou a virtuální realitou, (2012); dies., Pravda zvitězila. Výtvarné umění a husitství 1380-1490, S. 53 u.n.; ausserdem O. Halama, Otázka svatých, S. 95-129; G. P. Marchal, Das vieldeutige Heiligenbild. Bildersturm im Mittelalter, in: Macht und Ohnmacht der Bilder. Reformatorischer Bildersturm im Kontext der Europäischen Geschichte, „Historische Zeitschrift. Beihefte", New Series, 33 (2002), S. 307-332.

45 Synody diecezji wrocławskiej i ich statuty, hg. v. J. Sawicki, (Concilia Poloniae. Źródła i studia krytyczne 10, 1963), c. 55, S. 454-455; H. Manikowska, Ruch pielgrzymkowy na Ślasku w średniowieczu - problemy badawcze, in: Peregrinationes w kulturze dawnej Europy, S. 235-236, Anm. 44; K. Dola, Problemy kościelno-duszpasterskie $w$ diecezji wrocławskiej $w$ XV wieku, „Śląski Kwartalnik Historyczny Sobótka“, 41, 4 (1986), S. 531.

46 Diese Situation charakterisierte unlängst: F. Machilek, Schlesien, Hus und die Hussiten 1403-1435, in: Die Hussitische Revolution. Religiöse, politische und regionale Aspekte, hg. v. F. Machilek, (2012), S. 109-141. 
Stände mit den schlesischen Herzögen (mit dem Münsterberger Herzog Johann an der Spitze) gegen die Hussiten im November 1425 hatte der radikale Flügel der Hussiten - die Orebiten (Waisen) - unter Führung des Priesters Ambrož Wünschelburg erobert. Zum Symbol des antihussitischen Widerstandes wurde der hiesige (1407 als Altarist notierte) katholische Pfarrer Nikolas Mägerlin (Megerlein, Megerleyn), der sich weigerte, in Verkleidung vor den Hussiten aus der Stadt zu fliehen, weil dies, wie er erklärte, seinem Priesterstatus Abbruch tun würde. 1425 wurde er von den Hussiten auf dem Scheiterhaufen verbrannt, weil er die Annahme der „Vier Artikel“ verweigerte, und um seinen Tod begann sich schon bald darauf eine von dem Bolkenhainer Kaufmann Martin Kotbus (Martin von Bolkenhain) verfasste literarische Legende über sein Martyrium zu ranken ${ }^{47}$. Den Höhepunkt der Kämpfe bildete

47 Chronik des Martin von Bolkenhain, hg. v. F. Wachter, in: Geschichtschreiber Schlesiens des XV. Jahrhunderts, hg. v. ders., (Scriptores rerum silesiacarum 12, 1883), S. 1-18 (hier S. 3-4); Urkunden und Regesten zur Geschichte der Graffschaft Glatz von 1401 bis 1500, hg. v. F. Volkmer, W. Hohaus, (Geschichtsquellen der Graffschaft Glatz 2, 1888), S. 145-146. Siehe: A. Bach, Urkundliche Kirchengeschichte der Grafschaft Glaz: Von der Urzeit bis auf unsere Tage, (1841), S. 61; C. Grünhagen, Die Hussitenkämpfe der Schlesier 1420-1435, (1872), S. 99-102; P. Bretschneider, Die Hussiten in Wünschelburg, in: Die Hussitennot im Glatzer Lande. Gedenkblätter zum Fünfhundertjahrtag des Gefechts am Roten Berge, hg. v. F. Albert, (Glatzer Heimatschriften 20, 1928), S. 39-42: zusammen mit einer Edition der ins zeitgenössische Deutsch übersetzten Chronik (ebenda, S. 40-42); Herzig, Ruchniewicz, Dzieje Ziemi Kłodzkiej, S. 78. Die Zeit der Hussitenkriege behandelt: F. Albert, Die Husiten vor Glatz, in: Die Hussitennot im Glatzer Lande, S. 48-54; B. Bretholz, Der Ursprung der Husitenkriege und ihr Uebergreifen auf die Grafschatz Glatz, „Glatzer Heimatblätter“, 14 (1928), S. 122-131; U. Lincke, Die Einfälle der Husiten in die Grafschaft Glatz und das Gefecht am Roten Berge, ebenda, S. 150-155; A. Neumann, Die katholischen Märtyrer der Hussitenzeit, (1930), S. 131-135; M. Cetwiński, Pradzieje i średniowiecze, in: Kłodzko. Dzieje miasta, hg. v. R. Gładkiewicz, (1998), S. 49-50; K. Bartkiewicz, Dzieje Ziemi Kłodzkiej w wiekach średnich, (Monografie Śląskie Ossolineum 28, 1977), S. 153-158; Šmahel, Husitská revoluce, 3, S. 168, 373, Anm. 322; Machilek, Schlesien, Hus und die Hussiten, S. 130, Anm. 94: dort weitere Literaturangaben. Nicht bestätigt wird die Legende über Mägerlin in Cronica monasterii canonicorum regularium (S. Augustini) in Glacz = Kronika klasztoru kanoników regularnych (św. Augustyna) w Kłodzku, hg. v. W. Mrozowicz, (2003), S. 30-32; W. Mrozowicz, Kronika klasztoru kanoników regularnych w Kłodzku. Ze studiów nad 
die Niederlage des Münsterberger Herzogs Johann am 27. Dezember 1428 gegen die husstischen Heere bei Altwilmsdorf (Stary Wielisław) in der Nähe von Glatz. Die schließliche Abwehr der Hussiten und der Schutz vor dem Hussitismus in der Grafschaft Glatz wurde außerdem der Fürsprache der Jungfrau Maria zugeschrieben, die im Glatzer Madonnenbild verehrt wurde. Die hussitischen Überfälle gegen das Glatzer Land hörten erst 1434 ganz auf ${ }^{48}$.

In den erwähnten beiden Quaestionen 3 und 4 seines Traktats präsentierte Wünschelburg eine ausführliche bildliche Darlegung. In Quaestion 3 besprach er die offizielle Lehre der Kirche und verteidigte den Stellenwert der Bilderverehrung im Kult besonders gegen deren wyclifische und hussitische Infragestellung, um dann in Quaestion 4 zur Kritik und Verurteilung der Missbräuche im Bilderkult und der Heiligendarstellung überzugehen.

Ausgehend von terminologischen Grundlagen legte Wünschelburg vorher den Begriff „imago“ aus, den er dreifach erklärte. Erstens ist das Bild eine Figur, die die Konturen oder Umrisse (lineamenta) von jemandem darstellt, aber "non est eiusdem materie cum ipso“, wie z.B. bei einer Statue des Herkules. Zweitens stellt es die Konturen dar und „est eiusdem materie cum eo", aber es ist keine treue Kopie (non numero), sondern eine scheinbare Ansicht (specie), so wie der Sohn ein Bild des Vaters ist. Drittens stellt es die Konturen dar und „nec est eiusdem materie“, sondern enthält eine gewisse Ähnlichkeit (similitudinem eius). Diese letzte Definition bestimmt die Bedeutung des Begriffs

średniowiecznym dziejopisarstwem klasztornym, (2001), S. 154; ders., Konwent kłodzki i jego kultura w XV wieku w świetle własnej kroniki, in: Święty Stanisław Kazimierczyk CRL (1433-1489). Postać - środowisko - kultura - dziedzictwo, hg. v. K. Łatak, (2010), S. 250-262, sondern erinnert lediglich an die heroische Haltung des Glatzer Augustianerpriors Heinrich Vogtsdorf, der die Bewohner zur aktiven Verteidigung gegen die Hussiten aufgerufen haben soll.

48 Cetwiński, Pradzieje i średniowiecze, S. 50; Bartkiewicz, Dzieje Ziemi kłodzkiej, S. 158. 
„imago" buchstäblich am besten ${ }^{49}$. Da die Auslegung Wünschelburgs grundsätzlich immer in Richtung einer Offenlegung der Irrtümer des abgöttischen Bilderkultes ging, erklärte er dann, Petrus Lombardus folgend, den Unterschied zwischen den Begriffen „similitudo“, ,imago“ und ,idolum“.

Mit „similitudo“ haben wir es dann zu tun, wenn in Gold oder in Holz eine Ähnlichkeit des Aussehens wiedergegeben wird, z.B. einer Schlange oder eines Widders, und mit einem ,idolum“ immer dann, wenn ein bestimmter Zustand (dispositio) wiedergegeben wird, der nicht augenfällig sichtbar ist, sondern eine geistige Projektion darstellt, z.B. wenn einer als Mensch geborenen Gestalt der Kopf eine Hundes hinzugefügt wird. Da ihm kein natürliches Aussehen entspricht, sagt der hl. Paulus zu Recht: „Wir wissen, dass es in der Welt keine Götzen gibt" (1 Kor 8, 4). Götzendienst ist somit eine Verehrung (latria) und ein Dienst (servitium), der eigentlich Gott allein gebührt, aber mit Hilfe teuflischer Künste den Götzen dargebracht wird ${ }^{50}$.

Wünschelburg wiederholt die Definition und Klassifizierung des Götzendienstes auf der Grundlage der obligatorischen Auslegung des hl. Thomas von Aquin in der Summa theologica ${ }^{51}$. Götzendienst entsteht immer dann, wenn die allein Gott gebührende Ehre irgendwelchen von Menschenhand gefertigten Bildern, anderen Menschen, Geschöpfen oder den Dämonen dargebracht werde (infolge von Einflüsterung durch die Dämonen selbst). Wenn der Götzendienst verboten ist, darf man dann an der Berechtigung der Riten in der Kirche Zweifel hegen, da die Bilder im Kult doch erlaubt sind? - fragt der Autor.

49 BUWr., Sign. I F. 212, f. 239rb. Wünschelburg zitiert an dieser Stelle Hugon Ripelin de Argentina, Compendium theologicae veritatis, in: Albertus Magnus, B. Alberti Magni Ratisbonensis episcopi, Ordinis Praedicatorum, opera omnia [...], hg. v. A. Borgnet, 34 (1895), Lib. I, c. VI, in: B. Alberti Magni Opera omnia, hg. v. S. C. A. Borgnet, 34 (1896), S. 7-8.

50 BUWr., Sign. I F. 212, f. 239va.

51 Ebenda, f. 240ra; Thomas de Aquino, Summa theologiae, II.II, in: Sancti Thomae Aquinatis Opera omnia iussu impensaque Leonis XIII P.M. edita, 9 (1897), S. 309. 
Diese grundsätzliche Frage behandelt er auf scholastische Weise durch Erörterung aller Argumente „pro et contra“. Denn einerseits bezeugt die Autorität des Alten Testaments: „Du sollst dir kein Gottesbild machen und keine Darstellung von irgendetwas am Himmel droben, auf der Erde unten oder im Wasser unter der Erde" (Ex 20, 4; Deut 5, 8). Wenn man schon keine Bilder anfertigen darf, dann darf man sie erst recht nicht verehren, konkludiert er in diesem Teil. Andererseits bezeugt dieselbe Autorität der Bibel andere Beispiele der Verwendung von Bildern zur Unterweisung derer, die nicht lesen können, wobei hier offensichtlich die in dieser Epoche topische Definition der Bilderverehrung (Ikonodulie) als Instrument religiöser Didaktik wie z.B. in der Biblia pauperum im Hintergrund steht (Ex 25, 18-22, 37, 7; Jes 6, 1; Ez 1, 15; Offb 4, 6), wie sie auch der im Traktat zitierte Johannes Damascenus vertrat ${ }^{52}$. Es muss betont werden, dass Wünschelburg in diesem Fall besonders die memorativen Vorzüge der Bilddarstellung hervorhebt, die in der Kirche „ad rememorandum sancta memoria digna, quia non omnes noscunt litteras" dient, und darauf in der Generalkonklusion noch zurückkommt ${ }^{53}$. Die Apostel selbst haben Bilder in den Kult eingeführt, auch wenn er zugibt, dass die Bibel dies nicht bestätigt. Wünschelburg erinnert jedoch mit Eusebius von Caesarea und Johannes Damascenus an die berühmte Legende über den König Abgar V. von Edessa und das Mandylion als Acheiropoietos, als Ikone Christi. In der Version des Leipziger Theologen klingt sie wie folgt: Der kranke König schickte einen Maler als Boten zu Christus, der ein Bildnis von ihm anfertigen sollte, was sich wegen des von seinem heiligen Antlitz strahlenden Glanzes jedoch als unmöglich erwies. Ergriffen von

52 Gregorius I Magnus, Epistola CV. Ad Serenum Massiliensem Episcopum, hg. v. J.P. Migne, (Patrologia Latina 77, 1849), col. 1027-1028; G. Knapiński, Biblia pauperum. Rzecz o dialogu słowa i obrazu, „Nauka“, 4 (2004), S. 140; A. Weckwerth, Der Name „Biblia pauperum“, „Zeitschrift für Theologie und Kirchengeschichte“, 83 (1972), S. 1-33.

53 Handschrift in der BUWr., Sign. I F. 212, f. 241ra und: „Memoria ut summitur in proposito est specierum intelligibilium receptiva et conservativa", ebenda, f. 244vb. Siehe O. Halama, Otázka svatých, S. 99, 130. 
der Frömmigkeit des Königs berührte Christus sein göttliches Antlitz mit einem Tuch, auf dem sich sein Abbild einprägte. Danach sandte er es dem wartenden Abgar ${ }^{54}$. Auf diese Legende beriefen sich in den damaligen ikonoklastischen Diskussionen auch andere Autoren, u.a. die hussitischen Theologen Nikolaus von Dresden, Jakobellus von Mies sowie Peter Payne. Der Erstgenannte sah die Abgar-Legende als unsicher, ungewöhnlich und letztendlich apokryph an, während Peter Payne die fromme Tradition billigte ${ }^{55}$. Für Nikolaus von Dresden stellten solche Beispiele wie die Berufung auf den Abdruck des Antlitzes Christi auf dem Schweißtuch der Veronika oder das angeblich vom hl. Lukas gemalte Bildnis der Jungfrau Maria lediglich Apokryphen dar, und er erklärte, dass wenn man sich schon auf die Apokryphen berufen wolle, man dann dort ja auch die Sage findet, dass die Leiber von Petrus und Paulus deshalb verborgen seien, damit sie von den Gläubigen nicht

54 „Unde allegat Damascenus libro IIII capitulo VIII, „quod rumor ad eum pervenerat, quod beatus Lucas pinxit imaginem tam Christi quam Beate Virginis. Et quod ille imagines habebantur Rome et secundum illas alie fuerunt depicte, que olim Ierosolimis habebantur. Narratur enim in Ecclesiastica historia, quod Christus ab Agaro gessimorum civitatis regi, qui pictorem suum miserat ed eum imaginem sui ipsius transmisit. Cum enim pictor non possit in faciem Christi, aciem visus sui infigere propter claritatis choruscationem. Christus devotionem regis attendens, vestimentum suum faciei applicavit et sic sui ipsius imaginem ei misit", sicut narrat Damascenus, ubi supra“, BUWr., Sign. I F. 212, f. 241ra. Johannes Damascenus, De fide orthodoxa, lib. IV, c. 16, col. 1172-1176. Es wird angenommen, dass diese Legende eine spätere Interpolation im Werk des Johannes Damascenus darstellt. Siehe die klassische Arbeit von E. von Dobschütz, Christusbilder. Untersuchungen zur christlichen Legende, (Texte und Untersuchungen zur Geschichte der altchristlichen Literatur 18, NF., 3, 1899); K. Wessel, Acheiropoietos, in: Reallexikon der byzantinischen Kunst, 1 (1966), S. 22-28; P. Plank, Staurotheka, in: Lexikon für Theologie und Kirche, 9 (2000), S. 941-942; E. Sauser, Die Verehrung des heiligen, lebenspendenden Kreuzes in der Ostkirche, „Trierer Theologische Zeitschrift", 112, 2 (2003), S. 85-89; L. Kretzenbacher, Kreuzholzlegenden zwischen Byzanz und dem Abendlande. Byzantinisch-griechische Kreuzholzlegenden vor und um Basileios Herakleios und ihr Fortleben im lateinischen Westen bis zum Zweiten Vaticanum, (Sitzungsberichte der Bayerische Akademie der Wissenschaften 3, 1995), S. 1-74.

55 Nicolai de Dresda „De imaginibus“, S. 226-227; Nechutová, Traktát „De ymaginibus", S. 330. 
übermäßig verehrt werden würden. Viel wichtiger sei es, das Leben der Heiligen zu verehren und ihre Taten nachzuahmen ${ }^{56}$. Den Abdruck auf dem Schweißtuch der Veronika sowie das Bild des hl. Lukas hält er nicht für sicher (incertum); als sicher erkennt er allein das Gesetz Gottes an, das als wahres Bild und Spiegel zur Erkenntnis des göttlichen Willens dient - wie Nikolaus von Dresden an anderer Stelle ebenfalls betont ${ }^{57}$. Wünschelburg begründete die christliche Ikonodulie mit den Worten von Johannes Damascenums: Die Bilder sind bestimmt zur Unterrichtung der Gläubigen, zur Darstellung frommer Beispiele sowie zur Weckung der Frömmigkeit, denn „magis ex visis quam ex auditis causatur" 58 .

Daraus leitete Wünschelburg eine wichtige Konklusion ab. Wenn die Verehrung „ex commemoratione imaginis“ dargebracht wird, dann ist eine Adoration „ex commemoratione vivi hominis" berechtigter. Das Bild des lebenden Menschen ist würdiger (potior) als das aus Holz oder Stein. Deshalb muss Gott mehr als der inkarnierte und nicht bloß als der vorgestellte Christus verehrt werden ${ }^{59}$. Wünschelburg erklärte, dass sich die Anbetung Christi in seinem inkarnierten Aussehen aus

56 Nicolai de Dresda „De imaginibus“, S. 226; Nechutová, Traktát Mikuláše z Dráždan, S. 152.

57 Nicolai de Dresda „De imaginibus", S. 227.

58 „Sunt autem secundum Damascenum tres cause institutionis imaginum. Prima propter instructionem laicorum, quibus imagines adhibentur loco librorum. Secunda ut incarnationis misterium et sanctorum exempla nobis frequentius infigerentur. Tertia ad excitandum devotionis affectum, qui magis ex visis quam ex auditis causatur": BUWr., Sign. I F. 212, f. 241ra-b; „hos tanquam imagines, exempla et similitudines ac veluti illiteratorum libros venerari nos oportet et osculari, oculisque et labiis et corde complecti“: Joannes Damascenus, De imaginibus oratio II, 10, col. 1294 und ders., De imaginibus oratio I, 13, col. 1242-1243; ders., De fide orthodoxa, lib. IV, c. 16, col. 1158.

59 „Nam imago vivi hominis est potior quam imago lignea vel lapidea, ergo magis licite debeo adorare Deum vel Christum in homine quam in imagine": BUWr., Sign. I F. 212, f. 241rb. Siehe: J. Nechutová, Prameny předhusitské, S. 33-34: über die ähnlichen Ansichten bei Bernhard von Clairvaux, Matthias von Janov, Jakobellus von Mies und Nikolaus von Dresden und Bartlová, Die Bildersturm, S. 46; dies., Pravda zvitězila, S. 99 u.f. 
dem Akt der Menschwerdung ergibt, von der das Neue Testament berichtet. In einem polemischen Ton unterstrich er jedoch, dass gerade dies von den Häretikern, von Wyclif und den Hussiten verneint werde, besonders in Bezug auf die Heilige Dreifaltigkeit. Sie fragen: Auf welche Weise könnten wir das geistige, göttliche Wesen im Bild wiedergeben, da wir seine sichtbare Gestalt doch nicht kennen können? Wünschelburg bemerkte, dass sich das Konzil in Basel u.a. gegen solche Behauptungen richtete und die Unfehlbarkeit des Dogmas von der Heiligen Dreifaltigkeit bestätigte ${ }^{60}$. Die Bibel beschreibe doch die körperlichen Glieder des sichtbaren Gottes: seine Hände, Füße, Schultern, Finger, Bauch, Arme, Augen, Ohren, Eingeweide und Herz, d.h. alle dieselben Glieder, aus denen auch ein Mensch bestehe - fährt der Leipziger Theologe fort. Welche Schuld trägt daher der Sünder, wenn er Gott Augen verleiht, die doch von der Bibel bestätigt sind? Wenn die Heilige Schrift dies mit Worten schildert, warum sollte es der Künstler dann nicht auch mit Bildern tun dürfen? Dies bezeugen u.a. die Bildnisse der mitleidenden Maria, in ihren äußeren leiblichen Gesten des Schmerzes und der Trauer während des Leidens und Sterbens des

60 „Sed in Novo Testamento Deus factus est homo, potest in sua imagine corporali adorari, huic autem traditioni et usui Ecclesie de imaginibus contradixerunt heretici, hussite et Wicleff et maxime Trinitatis imagini fulminant anathema, ubi pater speciem viri habet senis, Filius iunioris et Spiritus Sanctus columbe typum habet, dicentes quomodo spiritualem et in circumscriptibilem divine essentie [f.241 va], quam cogitare non possumus sensibili forma, depingere curamus? Et pater inquit, homo non erat nec est visus ut homo, qua ergo audacia audent sibi imaginem hominis, quam minime recognovit. Huic errori Wicleff et hussitarum de hac Trinitate volens obviare sacrosanctum concilium Basiliense, sigillum suum plumbeum sub hac forma Trinitatis fecit insigniri, quod tamen velut rite et legittime congregatum, errare non potest, ut patet XVII di. Per totum cum ipsum dicat illud Psalmus 22: „Dominus regit me et nihil mihi deerit“. Respondeant ipsi Wickleff Scripture Sancte, qua audacia ipsi hoc faciant. Nam in Psalmo dat propheta domino Deo manus dicens Psalmo XVIII: „Opera manuum eius annuntiat firmamentum“, BUWr., Sign. I F. 212, f. 241rb-241va. Siehe auch: ,in veteris testamento non licuerunt (sic) imagines fieri, quia deus nondum fuit incarnatus", Petri Zatecensis liber diurnus de gestis Bohemorum in concilio Basiliensi, S. 343. 
Herrn, die darüber hinaus eine natürliche äußere Reaktion auf das innere Leiden bildeten ${ }^{61}$.

Wünschelburg wiederholte die Frage nach der angeblich durch Benutzung des Pinsels (pincellus) begangenen Sünde, mit dem ähnlich wie mit der Feder oder mit der Schrift Gott abgebildet wird, da doch Gottvater bzw. der Sohn in der Bibel in menschlicher Gestalt dargestellt werde, als er sich in sichtbarer Gestalt als Vater oder Sohn offenbarte und mit denen Gespräche führte, denen er dies seinem Willen gemäß tun wollte, und zwar in einer solchen Gestalt, wie er sie selbst gewählt hat, auch wenn die Anhänger Wyclifs und die Arianer dies bestreiten ${ }^{62}$. In leiblicher Gestalt wurde sowohl der Vater als auch der Sohn gesehen, aber nicht in der, in welcher ihn die göttliche Natur formte, sondern in einer solchen, die er freiwillig gewählt hat. Die Schrift bezeichnet die Personen Gottes, des Vaters oder des Sohnes, keineswegs als Menschen, wie Wyclif dies auslegte ${ }^{63}$, noch den Heiligen Geist als Taube, in deren

61 „Breviter, Ecclesie scriptura omnia membra humani corporis Deo Patri designavit, quid deest ne totum hominem possideat, qui possidet omnem partem. Sed quod Scriptura facit verbis, cur non artifex facit signis? Quam culpam incurrit peccator dans Deo oculum, quem scriptura concessit? Numquid, dicit Oracius pictoribus atque poetis, quibus addenda fuit semper equa potestas? Pictura etiam solent fieri, quo Beata Virgo plorat et plangit capillos trahit et quasi cadens teneatur et huiusmodi. Cum tamen Evangeliam dicat eam stetisse iuxta crucem et plorantium et gementium potius sit sedere resolutis viribus ex dolore et spiritibus vitalibus recurrentibus ad cor exterioribus membris relictis, ut dictur Psalmus 136: „Super flumina Babilonis illic sedimus et flevimus". Cum autem Beata Virgo, de qua non est dubium, quando ipsa tertiam et quartam etatem interioris spiritualem attigit nihil inordinatum in gestibus suis ostendit. Nec tamen vana et false sunt huiusmodi picture. Tantus enim dolor quam habuit ex sua natura, habet tales extensiones membrorum et casum inducere solet": BUWr. Sign. I F. 212, f. 241va.

62 „An etiam rederendo ad propositum maius peccatum circa hanc rem incurrit pincellus, quam penam imago, quam littera dum vero transsumpto pincello Deus imaginem suam depinxit in anima. Et ipse invisibilis Deus Pater in forma hominis frequenter apparuit, quantumcumque wicleffifiste hoc negent, ut opem conferant arrianis, qui ideo negabunt patrem unquam visibilem, ut visibili filio maior esset", ebenda, f. 243ra.

63 „Visum ergo profitetur scriptura patrem visum filium, visum spiritum sanctum corporali specie non quam natura deitatis formavit, sed quam voluntas elegit nec tamen 
Gestalt er gesehen wurde. Selbst diejenigen, die die Heilige Dreifaltigkeit in drei menschlichen Gestalten darstellen, erschüttern damit die Fundamente des Glaubens nicht, wie dies Gen 18, 1 sowie die von Wünschelburg zitierte Autorität des hl. Augustinus in De Trinitate bezeugt: „Wenn sich Abraham nur ein Mann gezeigt hätte, könnte man ihn für den Sohn Gottes halten. Aber hier wurden drei Männer gesehen und es wird nicht gesagt, dass einer von ihnen die anderen in Haltung, Alter oder Kraft überragt hätte. Warum sollten wir dann nicht annehmen, dass sich auf sichtbare Weise und durch Vermittlung der sichtbaren Schöpfung hier die Gleichheit der Dreifaltigkeit sowie ein und dasselbe Wesen in drei Personen offenbart hat?"64.

Die aus dem Geist der devotio moderna stammende Ansicht, dass dort, wo es an Fähigkeiten zum Verständnis mangelt, aber nicht an Liebe, der Geist sich zum Dienst am Glauben neigt, bereitete den Leser auf die Konklusion vor und kündigte die nächste, vierte Quaestion des Traktats $a^{65}$. Ich sehe nicht, wie die Kirche den Zustand rechtfertigen könnte, in dem sie sich befände, wenn man wegen einiger Primitivlinge, Häretiker, Märchenerzähler und Heuchler die Darstellungen beseitigen würde, „quamdiu saltem non plus obesse debeant quam prodesse" - so fragte Wünschelberg in rhetorischem und ausdrücklich empörtem Ton ${ }^{66}$.

Wünschelburg behielt sich jedoch vor, dass wenn sich die Kirche korrekt der Bilder bedienen wollte, die einfachen Gläubigen vorsichtig und gewissenhaft darüber belehrt werden müssten, damit diese versu-

pater dicendus est homo aut filius ante incarnationem dicendus est homo quamvis nisi sunt hominibus homines nec spiritus sanctus dicendus est columba, in cuius habitu visus est, quamvis hoc Wicleff dixit", ebenda, f. 243va-b.

64 Ebenda, f. 243vb; Augustinus, De Trinitate, hg. v. J.-P. Migne, (Patrologia Latina 42, 1843), Lib. II, c. 11, 20, col. 858.

65 „Ubi autem capacitas deficit caritas ipsa non deficit, sed captivum submittat intelectum in obsequium fidei“: BUWr., Sign. I F. 212, f. 244ra.

66 Ebenda, f. 244ra. 
chen können, ihren Geist über die „presentia sensibilia“ zu erheben ${ }^{67}$. Diesen Satz, der die Quaestion 4 des Traktats mit ihrer Kritik an den mit dem Bilderdienst verbundenen Irrtümern unter den Gläubigen ankündigt, bekräftigte er durch eine ausführliche Äußerung des hl. Augustinus aus dessen „Kommentar zum Johannesevangelium“: „Es beschleiche keinen von euch, meine Brüder, ein fleischlicher Gedanke. Es kann ja die menschliche Schwäche nichts denken, als was sie zu tun oder zu hören gewohnt ist. Stellt euch also nicht gleichsam zwei Menschen vor Augen, den einen als Vater, den andern als Sohn, und den Vater als zum Sohne redend, wie du es machst, wenn du einige Worte an deinen Sohn richtest, indem du ihn ermahnst und belehrst, wie er reden soll, damit er, was er von dir gehört hat, dem Gedächtnis einpräge, und dann, wenn er es dem Gedächtnis eingeprägt hat, auch mit der Zunge hervorbringe, in Laute kleide und fremden Ohren mitteile, was er in die seinigen aufgenommen hat. Fasst die Sache nicht so auf, damit ihr nicht in euren Herzen Götzenbilder errichtet. An eine menschliche Form, an Umrisse menschlicher Glieder, an die Gestalt des menschlichen Fleisches, an diese sichtbaren Sinne, an Stellungen und Bewegungen des Leibes, an einen Dienst der Zunge und artikulierte Laute dürft ihr bei jener Trinität nicht denken, außer was die Knechtsgestalt betrifft, welche der eingeborene Sohn Gottes angenommen hat, da <er Fleisch geworden ist, um unter uns zu wohnen>. Da verbiete ich dir nicht, o menschliche Schwäche, an das zu denken, was du kennst, ja ich halte dich sogar dazu an. Wenn der Glaube in dir wahr ist, dann denke dir Christus so, aber aus der Jungfrau Maria denke ihn dir so, nicht aus Gott dem Vater. Er war ein Kind, wuchs wie ein Mensch, wandelte wie ein Mensch, dürstete und hungerte wie ein Mensch, schlief wie ein Mensch, litt endlich wie ein Mensch, wurde ans Kreuz gehängt, getötet und begraben wie ein Mensch; er stand in derselben Gestalt wieder auf, fuhr in derselben

67 „Quamquam aut sancta Ecclesia licite utatur talibus imaginibus caute tamen et sollicite informandi sunt rudes et simplices, ut conentur intellectum suum elevare ultra illa presentia sensibilia seu sui representat", ebenda, f. 244ra. 
Gestalt vor den Augen der Jünger zum Himmel empor und wird in derselben Gestalt zum Gerichte erscheinen"68. Ein allzu materielles, konkretes Denken vom leiblichen Aussehen Gottes ist ein häretischer Irrtum, entschied er. „Mit wem wollt ihr Gott vergleichen und welches Bild an seine Stelle setzen?", fragt er ironisch mit den Worten des Jesaja $(40,18)$. Denn dort, wo die Heilige Schrift von der leiblichen Gestalt Gottes spricht, spricht sie „methaforice et figuratim“ und bezeichnet auf diese Weise allein die göttlichen Attribute oder Taten „respectu creaturarum ad extra" 69 . Wenn sie von seinen Händen spricht, dann meint sie damit seine Wirk- oder Strafmächtigkeit. Wenn von seinen Augenlidern die Rede ist, dann sind die verborgenen Urteile Gottes gemeint. Das gleiche betrifft die Heilige Dreifaltigkeit. Man darf nicht meinen, dass die so entstandene Vorstellung der unbeschreiblichen Heiligen Dreifaltigkeit auf völlig ähnliche oder adäquate Weise der Wahrheit entspricht, denn in Wirklichkeit ist eine solche Vorstellung nur ein schwacher Schatten (tenuissima umbra) ${ }^{70}$. Die Heilige Schrift schreibt Gott menschliche Glieder „secundum methaphoram sive similitudinem“ zu, denn wie Johannes Damascenus sagt: „Simplex enim Deus est et non figuralis“71.

Die in polemischer Form redigierte Quaestion 3 des Traktats endet mit einer langen Liste ausgewählter körperlicher Glieder des menschlichen Leibes mit ihren jeweiligen metaphorischen Sinninhalten ${ }^{72}$.

Die darauffolgende, vierte Quaestion des Traktats besitzt eine andere Aussage. Sie ist eine Ergänzung der vorherigen und stellt in ihrem

68 Ebenda, f. 244ra; Augustinus, In Joannis Evangelium. Tractatus XL, hg. v. J.P. Migne, (Patrologia Latina 35, 1864), c. 4, col. 1687.

69, ,I]n quo scripturam loquentem de membris Dei tamquam hominis ut de occulis manibus ac pedibus ostendit loqui methaforice et figuratim designando per hoc quasdam Dei proprietates habitudines operationes vel opera Dei respectu creaturarum ad extra“: BUWr. Sign. I F. 212, f. 244va.

70 Ebenda, f. 244vb.

71 Ebenda, f. 244vb; Johannes Damascenus, De fide orthodoxa, Lib. I, c. 4, col. 798.

72 BUWr., Sign. I F. 212, f. 244vb-245ra. 
Inhalt eine schwere Anklage, Verurteilung und Korrektur zahlreicher Irrtümer der Christen selbst dar.

Wünschelburg widmete diesen Teil seiner gelehrten Abhandlung einer Kritik der abergläubischen Verehrung von Heiligenbildern und -statuen sowie der falschen Wunder. In der Einleitung schilderte er das wahrscheinlich aus eigener Erfahrung bekannte Beispiel eines besonderen Kultes, mit dem ein altes Holzkreuz in einer namentlich nicht erwähnten Stadt in der Diözese Bamberg verehrt und zum Ziel von Wallfahrten aus der nächsten Umgebung gemacht wurde. Dieses gnadenspendende Kreuz war, wie der Autor peinlich genau aufzählte, mit neun Überzügen aus Seide und drei aus zartem Leinen geschmückt. Diese Überzüge durften unter Androhung schlimmster Gefahren nicht abgenommen werden. In dem von Wünschelburg geschilderten Kult wäre sicher nichts Verdächtiges oder Abwegiges, wenn diese hölzerne Kreuzfigur nicht, wie der Autor unterstreicht, ausschließlich aufgrund ihres Alters verehrt worden wäre. Wie der Theologe berichtet, waren die Gläubigen nämlich der Ansicht, alte Figuren würden mehr göttliche Kraft besitzen als neue. Deshalb erzählten alte Frauen, sicher Verehrerinnen dieses Kreuzes, dass alle großen imagines erst sechzig Jahre nach ihrer Anfertigung Wunderkraft gewinnen würden. Wünschelburg sah in diesem Kult also Merkmale des Aberglaubens und der Unwahrheit und berichtete mit Bedauern, dass ,ex hoc sacramentum dignissimum eukaristie in modica habebatur reverencia" ${ }^{\text {"73 }}$. Die Absichten der Anhänger dieses beanstandeten Kultes waren für den Leipziger Theologen also überaus deutlich erkennbar. Eine solche Form der Verehrung ging über die im Christentum anerkannten Normen der Frömmigkeit hinaus und reduzierte sich auf das Alter der Figur oder auf ihr Aussehen, d.h. auf die bloße sichtbare Form oder Gestalt eines eigentlich toten Gegenstandes, anstatt sich auf den in ihrer Symbolik verborgenen devotionalen Inhalt zu beziehen - das Gedächtnis der Passion des Herrn oder das Geheimnis der Erlösung durch den Tod Christi.

${ }^{73}$ Ebenda, f. 245ra-b; Hertel, Abergläubische Gebräuche, S. 277. 
Der von Wünschelburg erwähnte Kult war jedoch kein Einzelfall, denn ein Zeitgenosse des Autors, der Kanzler der Pariser Universität Johannes Gerson, berichtete in einem seiner zahlreichen Traktate über das religiöse Leben von einem ähnlichen Ereignis und rügte die Überzeugung vieler Gläubigen von der Wunderkraft oder Göttlichkeit heiliger Darstellungen aufgrund ihrer alten Herkunft oder figuralen Schönheit ${ }^{74}$.

Dabei ist es sehr wahrscheinlich, dass sich beide Autoren in diesem konkreten Bericht auf die Autorität des Pariser Bischofs Wilhelm von Auvergne stützten, der bereits im 13. Jahrhundert in De fide et legibus in einem ähnlichen Ton notiert hatte: „Dicunt enim, omnes imagines sexagesimo anno a factione sua virtutem sortiri et quamdiu duraverint obtinere "75. Sicher ist, dass der in Wünschelburgs Bericht inkriminierte Kult heiliger Darstellungen den Verdacht auf abergläubische Irrtümer weckte. Einem Heiligenbild aufgrund seiner visuellen Attribute oder seines Alters Wunderkräfte zuzuschreiben, anstatt aufgrund des frommen Inhalts, den es widerspiegelte, kam einem Götzendienst nahe, denn gerade die Heiden hatten ja von Menschenhand geschaffene Statuen verehrt ${ }^{76}$.

Wenn Wünschelburg in der Einleitung der behandelten Quaestion das zu seiner Zeit nicht seltene Phänomen sich spontan verbreitender Kulte heiliger Bilder oder Figuren illustrierte, dann fand er damit einen Vorwand zur gründlicheren Kritik jeglicher erfundener Wunder sowie der falschen und irrigen Verehrung heiliger Bilder und Darstellungen

74 Johannes Gerson, Quaedam argumentatio adversus eos, qui publice volunt dogmatizare seu praedicare populo, quod si quis audit missam, in illo die non erit caecus nec morietur morte subitanea et talia multa, in: ders., Opera Omnia, hg. v. L. E. Du Pin, 2 (1706), f. 522; A. Franz, Die Messe im deutschen Mittelalter, (1902), S. 301.

75 Guilielmi Alverni episcopi parisiensis De fide et legibus, in: William of Auvergne, Opera Omnia, Venetiis. Ex Officina Damiani Zenari (1591), c. XXIII, f. 64.

76 „Similiter circa alias ymagines aliorum sanctorum eadem supersticio uel similis fieri contingit [...] et quia cumprimis omnis talis sit ad ydolatrandum eo": BUWr., Sign. I F. 212, f. 245rb; Bartlová, Der Bildersturm, S. 37-38. 
im weiteren Verlauf des Traktats ${ }^{77}$. Der Theologe schien sich der Neigung besonders einfacher Menschen zu allen Arten von Wundern bewusst zu sein, und die kritisierten Erscheinungsformen abergläubischer Irrtümer in den Kulten heiliger Darstellungen resultieren „ex eo, quia rudis populus solum suos sensus, insequens fortiter movetur a talibus ymaginibus" und aus ihrer Wertschätzung der Pracht und Geschicklichkeit bei der Herstellung dieser Bildnisse, noch verstärkt durch den äußeren Prunk der mit dieser Anbetung verbundenen Riten, Gesten und Zeremonien. All dies bewirkt, dass die Gläubigen in götzendienerische Irrtümer verfallen ${ }^{78}$. Wünschelburg räumte also ein, dass die figurativen Heiligendarstellungen der Perzeption der Gläubigen besser zugänglich sind, weil es unerfahrenen Geistern leichter falle, mit Verstand und Phantasie eine geschaffene und mühelos wahrgenommene

$77 \mathrm{Zu}$ diesem Thema: J. Kracik, Święte obrazy wśród grzesznych sarmatów. Ze studium nad recepcja kultowego dziedzictwa, „Nasza Przeszłość, 76 (1991), S. 141-192. Zahlreiche ähnliche Beispiele der Verehrung von Heiligenbildern und -figuren bieten die Schriften vieler spätmittelalterlicher Superstitiologen mit ähnlichem Inhalt, siehe z.B.: Johannes von Frankfurt, Questio, utrum potestas cohercendi demones fieri possit per caracteres, figuras atque verborum prolationes, in: Hansen, Quellen und Untersuchungen, S. 77; Tomas von Haselbach, De decem praeceptis, hg. v. A. E. Schönbach, Zeugnisse zur deutschen Volkskunde des Mittelalters, „Zeitschrift des Vereins für Volkskunde“, 12, 1 (1902), S. 10; Nikolaus Magni von Jauer, De superstitionibus, BUWr., Sign. I F. 313, f. 269ra, wo ein „wundertätiges“ Bild der hl. Apollonia erwähnt wird, von dem erzählt wurde, es besäße die Kraft, alle zukünftigen, jetzigen und vergangenen geheimen Dinge $\mathrm{zu}$ offenbaren, was als ein Beispiel für Geomantie bezeichnet wird. Siehe auch „Exemplum": Ymago crucifixi dat sangwinem hg. v. J. Klapper, Erzählungen des Mittelalters in deutscher Übersetzung und lateinischen Urtext, (1914), S. 307, Nr. 91. Neben den weiter unten besprochenen Beispielen erwähnt Wünschelburg selbst die Verehrung des bloßen Querbalkens eines Kreuzes in einer bestimmten Stadtkirche: BUWr., Sign. I F. 212, f. 246rb.

78 „Similiter circa alias ymagines aliorum sanctorum eadem superstitio uel similis fieri contingit, quod fit et eo, quia rudis populus solum suos sensus insequens fortiter movetur a talibus ymaginibus et ob apparentiam eoram splendidam et artificiosam et quia cum pronus omnis talis sit ad ydolatrandum eo, quod facilius conceptus suos vel ymaginationem circumscribit et magis favorabiliter terminat ad creaturam, quam ad deitatem, quia sunt sibi talia proprinqua sue facultati naturali“, ebenda, f. $245 \mathrm{rb}$. 
Sache zu erfassen, die darüber hinaus zur natürlichen, sichtbaren Welt gehört, als das Wesen der Göttlichkeit in ihrer transzendenten und unsichtbaren Existenzweise (Form). Denn es sei leichter, an die göttliche Kraft dieser visuell erkennbaren Bilder zu glauben, angesichts des Unwissens und der Unkenntnis des Bildes des unvorstellbaren Gottes, den nach den Worten des hl. Johannes $(1,18)$,niemand je gesehen hat" - schlussfolgerte der Theologe ${ }^{79}$. Aber weder die Schlichtheit des Verstandes noch die angeborene Unvollkommenheit der Sinne, mit denen der Mensch eben nur die Dinge dieser Welt zu beurteilen imstande ist, können solche Kultpraktiken rechtfertigen, sondern diese bilden vielmehr einen zu satanischen Täuschungen führenden Weg. Denn die Dämonen machen sich lustig über die Menschen und bewirken, dass sie, benommen von sinnlichen Phänomenen, „den Kopf verlieren“ und in der Konsequenz keinen lebendigen, sondern einen toten Glauben bekennen - konstatierte Wünschelburg ${ }^{80}$. Wenn man also glaubt, dass solche kraft dieser Bilder gewirkten signa oder prodigia die Menschen heilen, dann unterliegt man den Einflüsterungen des Teufels und verehrt eigentlich ihn und nicht den im Bild dargestellten „Prototyp“"81. Die dämonologische Interpretation solcher Praktiken bestärkte den

79 „[F]acilius conceptus suos uel ymaginacionem circumscribit et magis fauorabiliter terminat ad creaturam, quam ad deitatem, quiasunt sibi talia propinqua sue facultati naturali“, ebenda, f. 245rb; „Et sic deinceps habet ergo proprium in corde hominum fatuitas alligata ab eorum principio, quod sunt prodigi diuini honoris et virtutum divinorum facile, quod ponit in rebus eas creatis quas videt, quia nescit neque possit deum ymaginari, quem non videt, sicut scriptum est Joh. 1,18 «Deum nemo vidit vnquam»" ebenda, f. 246va.

80 „Inter hec vnum et praecipuum est, quod iniquitas capciosa demonum potentes est valde in talibus ymaginibus, quia sunt dei et sanctorum et in templo uel domo dei dementare homines et ludificare, qui non fide viua habundant, sed mortua", ebenda, f. $245 \mathrm{rb}$.

81 Ebenda, f. 245va. Thomas de Aquino, Summa theologiae, III, c. 25, a. 2-3, in: Sancti Thomae Aquinatis Opera omnia iussu impensaque Leonis XIII P.M. edita, 11 (1906); Gvillelmi Dvranti Rationale divinorvm officiorvm, hg. v. A. Davril, T. M. Thibodeau, 1 (Corpvs christianorvm. Continuatio Mediaeualis 140, 1995); O. Halama, Otázka svatých, S. 98-101; Bartlová, Die Bildersturm, S. 46 und R. Maniura, R. Shepherd, Intro- 
Theologen in der Überzeugung, dass die Dämonen - mit dem Einverständnis Gottes - die Menschen so perfekt irreführen können, dass sie ihren Wünschen und Neigungen folgend Gefallen finden am Tod Christi, seinem leidenden Leib und seinem Blut, worin man wohl eine Anspielung an die im erwähnten, verschollenen Traktat Wünschelburgs enthaltene Kritik der Wallfahrten nach Wilsnack und aller damals beobachteten Erscheinungsformen der Verehrung blutender Hostien oder des Blutes Christi erkennen kann ${ }^{82}$.

Durch welche Merkmale sollten sich daher die Formen korrekter Verehrung der Heiligenbilder manifestieren, und welche zeugten von diesbezüglich begangenen Missbräuchen und der Falschheit solcher Praktiken? - fragte der Leipziger Theologe. Wünschelburg situierte also auf gegenüberliegenden Polen die richtige Verehrung in Bezug auf den im Bildnis widergespiegelten „Prototyp“ („,cum relatione ad prothotipum“), der den Inhalt des Bildes ausmacht, und die falsche Verehrung, die mit den Gebetsabsichten den Bildern selbst dargebracht wird, die doch in Wirklichkeit nur tote Gegenstände sind und keinerlei göttliche Kraft in sich selbst besitzen ${ }^{83}$. Wünschelburg berief sich somit auf die in der mittelalterlichen Theologie fundamentale Interpretation solcher Praktiken, besonders auf die in ihnen postulierte Dichotomie zwischen der verehrten Gestalt und ihrer Vorstellung (imago-imaginatum) ${ }^{84}$. Darüber hinaus wandte er sich dagegen, solche Kulte, übrigens nicht nur im Falle der Bilder, ausschließlich in Kategorien irdischer Bedürfnisse wahrzunehmen, insbesondere im therapeutischen oder produktiven

duction, in: Presence. The Inherence of the Prototype within Images and Other Objects, ed. R. Maniura, R. Shepherd, (2006), S. 1-30.

82 „Permittit autem deus dyabolo sic decipere homines, qui secuntur sua desideria et indigne vniunt vocacione sua atque significacione ingrati corpori et sangwini domini nostri Ihesu Christi et eius morte amare": BUWr., Sign. I F. 212, f. 245va.

83 „Sed hoc dico, quod omnis ymagines pariformiter designant imaginata, siue prothopos et cruces Christum Ihesum crucifixum. Item ymagines sanctorum et cruces sunt venerande cum relacione ad prothotipum", ebenda, f. 246vb.

84 Kracik, Święte obrazy, S. 141-156. 
Bereich. Als Beispiel erwähnte er bestimmte Bräuche von Wallfahrern, wobei Übernahmen aus dem 1405 entstandenen Traktat De superstitionibus des ebenfalls aus Schlesien stammenden Heidelberger Theologen Nikolaus Magni von Jauer (Jawor) (1355-1435) mit ähnlichem Inhalt zu erkennen sind. Wünschelburg zitierte das Beispiel populärer Wallfahrten nach Aachen, wo die Pilger am Grab beichten, um der Armut zu entgehen und Reichtum zu erwerben. Der erwähnte Nikolaus Magni von Jauer fügte an dieser Stelle hinzu, dass die Gläubigen auf diesen Wallfahrten im Augenblick des Zeigens der Reliquien besondere Spiegel hochhielten und damit figurativ ihre irdischen Bedürfnisse manifestierten ${ }^{85}$. In diesem Brauch äußerte sich die Überzeugung, das Spiegelbild würde die Wunderkraft der Aachener Reliquien bewahren, die die Gläubigen dann nach Hause mitnehmen und dort länger aufbewahren könnten. An anderer Stelle erinnerte Wünschelburg, wenn auch überaus lakonisch, an die Praxis, das Gewicht von Knaben oder alten Menschen nach dem Gewicht des Weizens zu messen, gewiss ebenfalls zu therapeutischen Zwecken, wie wir dies auch in den Praktiken der Wallfahrer finden, und zwar in Form des Brauches, Votivgaben in der Form und mit dem genauen Gewicht kranker Glieder des Körpers darzubringen. Die Gläubigen meinten, diese Gabe würde den Körper des Kranken repräsentieren, der sie in der Hoffnung auf Genesung dem Heiligen als Opfer darbrachte ${ }^{86}$. Diese Praxis ging auf eine noch

85 Hertel, Abergläubische Gebräuche, S. 274. Bei Nikolaus Magni von Jauer, De superstitionibus, BUWr., Sign. I F. 313, f. 275vb: „Item speculorum et panum obiectorum ad ostensionem reliquiarum in Aquisgrani“; Bracha, Des Teufels Lug und Trug, S. 147.

86 Nach Hertela, Abergläubische Gebräuche, S. 274: „ponderacionis puerorum vel senum ad equalitatem siliginis“; A. Franz, Die kirchlichen Benediktionen im Mittelalter, 2 (1909), S. 462. Dieses Fragment aus Wünschelburgs Traktat ist ebenfalls eine Übernahme aus De superstitionibus Nikolaus Magni von Jauer: BUWr. I F. 313, f. 275vb. Eine ähnliche Überzeugung lag wohl auch dem Brauch zugrunde, Menschen z.B. mit Hilfe eines Fadens oder einer Schnur zu heilen; P. Pietsch, Kleine Beiträge zur Kenntnis des Aberglaubens des Mittelalters, „Zeitschrift für deutsche Philologie“, 16 (1884), S. 185-186: „Hostu dich lossin messin mit eynem roen faden“; J. Klapper, Deutsche Volksglaube in Schlesien in ältester Zeit, ,Mitteilungen der schlesischen Gesellschaft für 
vorchristliche Tradition kultischer Opfergaben zurück, deren verborgener Sinn sich auf eine Art Tauschhandel zurückführen ließ, im Sinne der bekannten Formulierung des hl. Augustinus: „Quicquod do, mihi accipio"87.

Aus den Aussagen des Autors über die den Bildern gebührende Verehrung resultierte eine weitere Direktive des Theologen, in der er die differenzierte und valorisierte Verehrung zahlreicher Bildnisse verwarf. Er entschied, dass diese in gleichem Maße verehrt werden müssen, ohne manchen von ihnen den Vorzug zu geben ${ }^{88}$. Aus ähnlichen Gründen, wie anzunehmen ist, wurde 1405 in Speyer und in Heidelberg vor das Tribunal der dortigen bischöflichen Inquisition ein Augustianereremit zitiert, der den Glauben vertrat, dass ein bestimmtes, kultisch verehrtes Klosterkreuz in Landau heiliger sei als andere Kreuze ${ }^{89}$. Letztendlich

Volkskunde“, 17, 1 (1915), S. 39, Nr. 7; Stanisław ze Skarbimierza, Sermo 47, in: Stanisław ze Skarbimierza, Sermones sapientiales, hg. v. B. Chmielowska, (Textus et Studia Historiam Theologiae in Polonia Excultae Spectantia 4, 2, 1979), S. 92-93 berichtet, dass auf diese Weise eine als „Maß“ bezeichnete Krankheit geheilt wurde, weil man annahm, diese würde den Kranken erst dann verlassen, wenn man auf seinen Körper Druck ausübt oder ihn fesselt. A. Witkowska, Zagadnienie mentalności religijnej w świetle „miracula" $z$ XII/XIV w., in: Kościót w Polsce. 1: Średniowiecze, hg. v. J. Kłoczowski, (1966), S. 620-621 erwähnt außerdem Votivgaben in Form von Kerzen, die nach dem Maß des Körpers oder des geheilten Gliedes geformt waren, das mit einer Schnur gemessen wurde, aus welcher dann der Docht der geopferten Kerze hergestellt wurde. Zu diesem Thema: F. Šmahel, Stärker als der Glaube: Magie, Aberglaube und Zauber in der Epoche des Hussitismus, „Bohemia. Zeitschrift für die Geschichte der böhmischen Länder“, 32, 2 (1992), S. 321, Anm. 10; K. Bracha, Mierzenie nicia i ważenie ciat. O pewnej praktyce wotywnej w średniowieczu, in: Cursus mille annorum. Prace ofiarowane Profesorowi Eugeniuszowi Wiśniowskiemu, hg. v. A. Kuźma, P. Plisiecki, L. Poniewozik, „Roczniki Humanistyczne", 47, 2 (2000), S. 61-72.

87 Augustinus, Sermo 198. De kalendis Januariis, II, hg. v. J.-P. Migne, (Patrologia Latina 38, 1845), c. 3, col. 1025.

88 „Item propter parem et uniformam significacionem pariter et uniformiter sunt venerande“: BUWr., I F. 212, f. 246vb.

89 Revocatio et refutatio articulorum Wernheri de Fridburgo: die Handschrift im Archiwum Archidiecezjalne i Biblioteka Kapitulna we Wrocławiu [Diözesanarchiv und Kapitelbibliothek in Breslau], Sign. 309, f. 75va: „Der achtend daz, daz crucz zu 
unterschied der Theologe in der Konklusion der diesbezüglich kritischen Befunde drei prinzipielle Ursachen, die zu falschen, gleichsam „wunderbaren“ Phänomenen und erfundenen Kulten führen. An erster Stelle erwähnte er, gemäß der dämonologischen Interpretation solcher Praktiken, die Schlauheit der Dämonen (astucia demonum), dann die menschliche Leichtgläubigkeit, besonders der leichter verführbaren Frauen (credulitas mulierum), und schließlich die Sündhaftigkeit der Geistlichen und der Laien sowie ihre Begierde nach materiellen Gütern (auaricia clericorum, similiter et laicorum) ${ }^{90}$. In der zuletzt genannten Ursache wird ein im reformatorischen Schrifttum des Spätmittelalters charakteristischer kritischer Ton erkennbar: nicht nur gegenüber den Formen des Lebens, der Religiosität und der Bräuche der Laien, sondern auch gegenüber den Einstellungen und dem Verhalten der Geistlichen selbst und ihrer mit den Geboten der Kirche nicht immer zu vereinbarenden Teilnahme an solchen Verdacht erweckenden Praktiken. Wünschelburg räumte ein, dass er sich gerade um die Geistlichen sorgte, die dem Volk in den Kirchen Gelegenheit zu solchen unwürdigen Praktiken und Missbräuchen boten und unterschiedliche Formen äußerlicher Verehrung solcher Darstellungen durchgehen ließen, als ob ein Bild verehrungswürdiger wäre als die anderen ${ }^{91}$. Nicht einmal der

den Augustinem ze laudenburg soll hailiger sin, dann anderen crucz, vnd daz man daz nit malen noch verenderen mug“. Siehe: F. W. E. Roth, Die Artikel Wernhers von Friedberg 1405, „Quartälblatter des historischen Vereins für Grossherzogtum Hessen“, 1 (1886), S. 42-46; R. E. Lerner, Werner di Friedberg intrappolato dalla legge, in: La parola all'accusato, hg. v. J.-C. Maire Vigueur, A. Paravicini Bagliani, (1991), S. 268-281; K. Bracha, Errores augustianina - eremity Wernera z Friedbergu w świetle inkwizycji heidelberskiej z 1405 roku, in: Klasztor w społeczeństwie średniowiecznym i nowożytnym, hg. v. M. Derwich, A. Pobóg-Lenartowicz, (1996), S. 471-481; ders., „Cristus in siner jogent vnd kintheit gewundert hart". IX-ty punkt oskarżenia brata Wernera $z$ Friedbergu w procesie z 1405 r., in: Inkwizycja papieska w Europie Środkowo-wschodniej, hg. v. P. Kras, (2010), S. 329-348.

90 BUWr., Sign. I F. 212, f. 247ra.

91 „Ve igitur illis timeo sacerdotibus et clericis, qui dant occasionem populo tales abhominaciones exercendi in templo dei dant quod spirituales indulgencias pro flec- 
Bericht des Evangeliums von der Frau, die durch Berührung des Saumes des Gewandes des Erlösers von Blutungen geheilt wurde (Mt 9, 20-22), stelle ein ausreichendes Argument zur Begründung solcher Praktiken dar, denn nach Ansicht Wünschelburgs sollten die im Evangelium geschilderten Wunder nicht nachgeahmt, sondern bewundert werden ${ }^{92}$. Trotz allem wahrte der Theologe in seinen Äußerungen ein gewisses $\mathrm{Maß}$ an Zurückhaltung und übernahm keine extremen Auffassungen. Im letzten Kapitel räumte er ein, dass in der herkömmlichen, über eine reiche Tradition verfügenden Bilderverehrung nicht alles schlecht sei, fügte aber hinzu, solche Formen des Kultes würden nicht selten böse Folgen haben, worüber man sich klar sein sollte und wovor die Gläubigen gewarnt werden müssen ${ }^{93}$. Wie wir bereits erwähnten, negierte Wünschelburg die Definition der christlichen Ikonodulie nicht, in der die Bilder als eine Schrift für Schriftunkundige angesehen wurden, aber wegen zahlreicher Missbräuche der auf diesem Gebiet und insbesondere wegen des zu beobachtenden Phänomens der Autonomisierung der nicht selten von ihrem Inhalt losgelösten Darstellungen empfahl er weitestgehende Vorsicht und akzeptierte lediglich, dass der Verehrung des Kreuzzeichens der Vorrang gebührte ${ }^{94}$.

tendo genua coram singularibus et specialibus ymaginibus, ut una ymago magis aliis sit in honore et admiracione hominum et stupore“, ebenda, f. 248ra.

92 „Quod miracula sanctorum novi et veteris testamenti sunt admiranda et non ad exemplum nostre imitacionis trahenda, multa enim tunc concedebantur, que nunc penitus prohibentur“, ebenda, f. 247rb. E. Demm, Zur Rolle des Wunders in der Heiligkeitskonzeption des Mittelalters, „Archiv für Kulturgeschichte“, 57 (1975), S. 300-344; B. Ward, Miracles and the Medieval Mind. Theory, Record and Event 1000-1215, (1987).

93 „Non dico, quod hoc in se malum sit, sed occasio mali inde sequentis. Aliquid enim prohibetur, non propter hoc, quod malum sit, sed propter illud, quod ex eo sequi possit“, BUWr., Sign. I F. 212, f. 248ra.

94 „Nec per hoc curo negare ymagines racionabiliter fieri in ecclesia, cum teneat vniuersitas sancte ecclesie et dicatur communiter et praesertim per Damascenum, quod ymagines sunt scriptura laycorum. Decoretur igitur templum ymaginibus huic ego non obsto, nec ullomodo contradico, dimminuo in talibus cautela sicut et in aliis habeatur", ebenda, f. $246 \mathrm{vb}$. 
Der hier in allgemeinen Zügen dargelegte Standpunkt des Leipziger Theologen gegenüber der hussitischen Ikonophobie einerseits und den Erscheinungsformen irriger Verehrung von Darstellungen der Heiligen und Gottes andererseits erweist sich somit als eine Stimme der Kritik an den häretischen ikonoklastischen Ideen und zugleich an den Missbräuchen und „Auswüchsen“ im offiziellen Kult. Darin kamen die reformatorischen Bestrebungen kirchlicher intellektueller Kreise zum Ausdruck, die die Religiosität von solchen Praktiken reinigen wollten, in denen die Grenzen zwischen tiefer Frömmigkeit und traditionellem Denken unscharf und manchmal sogar völlig verwischt waren. Die diesbezüglichen Bemühungen der reformatorisch gestimmten Geistlichkeit sollten zur Wiederherstellung der ursprünglichen Dimension rein christlicher Tiefe im Erleben und Manifestieren des Glaubens führen, die frei war von der Last bloß sinnlicher Empfindungen, und gleichzeitig die Idee der christlichen Ikonodulie gegen ihre völlige Ablehnung oder gegen die Infragestellung der Berechtigung der Bilderverehrung im Kult verteidigen, wie dies insbesondere seitens der Hussiten geschah.

Die Konfrontation der Ikonodulie mit der Ikonophobie und später in der Atmosphäre zunehmender Feindschaft der Ikonodulie gegen den offenen Ikonoklasmus mit chiliastischem Hintergrund bewegte sich, wie wir wissen, um zwei Theorien: ,imago-imaginatum“ sowie „scriptura laicorum“ im Kontext des Verhältnisses zwischen „latria“ und „dulia“",,adoratio“ und „,veneratio“. Das ideologische Schema gründete sich auf die Unterscheidung zwischen der dem Schöpfer allein gebührenden ,adoratio latria“ und der "veneratio dulia“ (oder wechselweise der „adoratio vicaria“ wie bei Wyclif) für die „imago “95. Die „,imagoimaginatum"-Beziehung bildet in dieser Theorie den Ausgangspunkt fast aller Polemiken, und die "scriptura laicorum“ ist das wichtigste Argument zur Begründung der geltenden frommen Praxis.

95 Nechutová, Prameny předhusitské a husitské ikonofóbie, S. 29, 31. 
Es besteht kein Zweifel, dass Wünschelburg ein Vertreter der zweiten der hier erwähnten, im Spätmittelalter dominierenden Ideen war. Dabei folgte er Johannes Damascenus. Das Problem bestand darin, dass die hussitische Ikonophobie, wie Jana Nechutová bemerkte, beiden Standpunkte feindlich oder zumindest kritisch und kämpferisch gegenüberstand. Der Hussitismus reagierte vor allem auf eine Praxis, in der die Bilder, um Begriffe aus Nechutovás Vokabular zu gebrauchen, auch wenn dieses etwas übertrieben erscheint, „paganisiert“ („,silně paganizována") waren ${ }^{96}$. Die Bildnisse wurden in der populären Religiosität nicht selten als personale Wesen angesehen, als heilige Gestalten. Wünschelburg wandte sich gerade gegen eine solche Kompensierung und Gleichsetzung des Werkzeugs der Expression, eines von Menschenhand gefertigten Bildes, mit dem Prototyp. Der Leipziger Theologe räumte ein, dass man in der religiösen Praxis viele Irrtümer und menschliche Ignoranz finden könne, was aber nicht Ausdruck der ideologischen Absichten der Kirche sei, sondern einen Missbrauch darstelle, der der Korrektur und oft sogar der Verurteilung bedürfe. Auf diese Weise verteidigte er die Orthodoxie, aber erst nach vorheriger Reinigung des Kultes, und nahm damit seinen hussitischen Gegnern die Argumente aus der Hand, auf die sie ihre Ikonophobie stützten.

Im Grunde genommen stimmten die Kritik des rechtgläubigen Theologen aus Leipzig und die der hussitischen Denker in vielen Punkten überein, denn beide warnten vor derselben Gefahr. Wünschelburg sprach vom Rückfall in den Götzendienst („cum pronus omnis talis sit ad ydolatrandum eo") und Matthias von Janov betonte, dass „ymagines similiter sicut deus sint adorande ${ }^{497}$. Auch verwarfen weder Matthias von Janov noch Jan Hus die Idee der „scripta laicorum“. Der Eine von Beiden bekannte unmissverständlich: „Ich versuche nicht die Bilder zu negieren, die in der Kirche racionabiliter gefertigt und angebracht wer-

96 Ebenda, S. 29.

97 Matthiae de Janov, Liber III, S. 37 (dist. 5, c. 10): „De operacione Sathane in Antichristo per suos". 
den“, da „tales ymagines sunt Scriptura laycorum“, und der andere, dass „materielle Bilder in der Kirche nicht als latria verehrt [...]“, sondern „racionabiliter" verwendet werden „propter simplicium ruditatem, quia nesciunt legere in codicibus, saltim videant in parietibus “98. Hus lehrte, dass es deshalb erlaubt („licite“) sei, vor Bildnissen Christi oder anderer Heiliger zu knien, wir dies aber nicht im Namen des Bildes tun dürften, sondern im Namen dessen, den es darstellt, weil das Bild „non propter se, sed propter ymaginatum" angefertigt wurde ${ }^{99}$.

Worin also bestand das Problem? Beide Seiten des Konflikts verwiesen auf dieselbe Ursache - den schlechten Bildungsstand der breiten Bevölkerung. Matthias von Janov sagte geradezu, es müsse begonnen werden „forte sopphista et logicus“ zu lehren, ohne Schaden im Gewissen und im Glauben. Er fügte hinzu, dass eine allzu allgemeine oder gar keine Erziehung im Glauben dem ungebildeten Volk leider sehr schadet. Aus diesem Grunde erlaubt die Kirche Bilder und lehrt, diese zu ehren und zu würdigen („honorandas et venerandas“), aber sie lehrt nie, diese zu verehren („colendas nusquam docuit vel statuit“) ${ }^{100}$. Ähnlich stellt Wyclif in einer seiner Predigten die Idee des „imagoimaginatum" in Frage, weil die Laien dadurch meinen könnten, dass solche Bilder „sint naturaliter sanctus“, solange das Volk nicht richtig unterwiesen werde. Aber leider, schrieb er, gebe es viel zu wenig gute Priester, die zu einer solchen Unterweisung fähig wären, damit die Gläubigen die Bilder dann auch richtig als „scriptura laicorum“ verste-

98 Matthiae de Janov, Liber V, S. 86 (dist. 6, c. 2); Johannes Hus, Expositio Decalogi, 2, 14, in: Spisy M. Jana Husi, hg. v. V. Flajšhans, (Sbírka pramenư českého hnutí náboženského ve XIV. a XV. století 1, 1903), S. 6; Johannes Hus, Super quattuor Sententiarum, 2, in: ebenda, (Sbírka pramenů 4-6, 1905), S. 415; Nechutová, Prameny předhusitské a husitské ikonofóbie, S. 31, Anm. 5.

99 Johannes Hus, Super quattuor Sententiarum, 2, S. 421; Nechutová, Traktát Mikuláše z Dráždan, S. 151 und Nicolai de Dresda „De imaginibus“, S. 220 sowie eine ironische Bemerkung an anderer Stelle, ebenda, S. 224.

100 Matthiae de Janov, Liber III, S. 37-38 (dist. 5, c. 10). 
hen ${ }^{101}$. Auf besondere Schwierigkeiten in der Erziehung der Gläubigen verwies Peter Payne im Falle der Lehre von der Heiligen Dreifaltigkeit, weil die bildliche Darstellung der Dreifaltigkeit eher zu Irrtümern als zum Wissen führt ${ }^{102}$. Diese Mängel in der religiösen Bildung sah Wünschelburg ganz ähnlich. Als bestes Mittel zu ihrer Behebung empfahl er gute Predigten, wie er dies in der Einführung zu seinem Traktat unterstrich. Darin erblickte er ein grundlegendes Antidoton gegen die Unvollkommenheiten der irdischen Welt, und er kritisierte die Passivität mancher Prediger in Zeiten, die an sich der besonderen Sorge um die Bildung der Gläubigen bedürfen ${ }^{103}$. Beide Seiten gaben auch dem Kult des lebendigen Gottes den Vorrang gegenüber seinen im Bild oder in Holz dargestellten Bildnissen, wozu Wünschelburg zu überzeugen bemüht war. Und an die „vivas ymagines creatas" erinnerte u.a. Jakobellus von Mies, denn „multo magis honorare tales ymagines vivas quam artificiales" ${ }^{104}$. In einer Frage unterschieden sich beide Seiten dennoch. In Wünschelburgs Traktat fehlt es an Anspielungen auf soziale und wirtschaftliche Themen wie im Hussitismus, d.h. auf den unnötigen Prunk, den Ehrgeiz und die Gefräßigkeit des Klerus und der Künstler auf Kosten der materiellen Hilfe für die Armen, wie dies u.a. von Matthias von Janov und Nikolaus von Dresden hervorgehoben wurde ${ }^{105}$. Letzterer, der übrigens unter dem Einfluss von Matthias von Janov stand, erblickte zwei grundsätzliche Ursachen der Bilderver-

101 Johannis Wyclif Sermones, hg. v. J. Loserth, 1 (Wyclif's Latin Works 11, 1887), S. 91-92; Nechutová, Prameny předhusitské a husitské ikonofobie, S. 32-33; O. Halama, Otazka svatých, S. 130.

102 Nechutová, Traktát „De ymaginibus“, S. 329.

103 „Et in hoc tempore multiplex medicina sapientie incarnate [...] Quinta est predicationis salutifere“: BUWr. Sign. I F. 212, f. 228ra-b.

104 Jakoubek von Střibr, Posicio de imaginibus, zit. nach Nechutová, Prameny predhusitské a husitské ikonofóbie, S. 34, Anm. 13.

105 Matthiae de Janov, Liber V, S. 90 (dist. 6, c. 3); Nicolai de Dresda „De imaginibus“, S. 223. Nechutová, Prameny předhusitské a husitské ikonofóbie, S. 33-34; Bartlová, Pravda zvítězila, S. 62, über die Einflüsse von Bernhard von Clairvaux. 
ehrung: die menschliche Dummheit, wovon das von ihm angeführte Beispiel einer Verehrung des Götzen Priapus zeugen sollte, sowie die Habsucht des Klerus ${ }^{106}$.

Wünschelburg äußerte sich nicht zu den radikaleren Standpunkten chiliastischer Kreise, sondern konzentrierte sich ganz auf ihre ikonophobe Kontestation, auf ihre Infragestellung der Richtigkeit der angeblich von der Autorität der Bibel nicht bestätigten und zu den menschlichen "adinventiones" zählenden Ikonodulie. Wir finden in seinem Traktat auch eine Abwehr der hussitischen Argumente, die Bilder würden die Aufmerksamkeit vom Hören ablenken, vom Wort, das in der böhmischen Reformbewegung über alles nobilitiert wurde, mit dem „officium praedicationis" an erster Stelle ${ }^{107}$. In seinem Tagebuch (Liber diurnus), einem Bericht über Beratungen mit den Hussiten in Basel, erwähnt der Autor Peter von Saaz (Žatecki) eine ähnliche Anschuldigung, dass "imago plus movet, quam scriptura vel precatio "108. Dagegen beharrte der Leipziger Theologe im Geiste der „scripta laicorum“ auf ihrer ergänzenden Funktion, ihrer Suggestivkraft, ihrer emotionalen, symbolischen, metaphorischen und vor allem memorativen Vorzüge. Aber wenn Nikolaus von Dresden einräumte, dass wenn ein Bild der Passion unseres Herrn verehrt werde, dann nicht „propter se ipsam“, sondern „propter passionem Christi in ipso depictam", und hinzufügte, dass sich dies der Erinnerung einpräge, so teilte er doch mit Wünschelburg den Memorisationswert einer solchen Anbetung und die alleinige Legitimierung der vom Leipziger Theologen unterstrichenen richtigen Verehrung

106 Nechutová, Traktát Mikuláše z Dráždan, S. 152; Nicolai de Dresda „De imaginibus“, S. 224: „Revera fecit hoc et facit hominum stuliticia et maxime sacerdotum avaricia“.

107 Nechutová, Prameny předhusitské a husitské ikonofóbie, S. 36; K. Bracha, „Semen est verbum Dei“. Postylla Carcer animae przypisywana Janowi Szczeknie, in: Amoenitates vel lepores philologiae, hg. v. R. Laskowski, R. Mazurkiewicz, (2007), S. 61-71.

108 Petri Zatecensis liber diurnus de gestis Bohemorum in concilio Basiliensi, 1, S. 343 . 
mit Bezug auf den im Bildnis widergespiegelten „Prototyp“109. Weniger überzeugend erscheint dagegen das Argument von der allegorischen Metaphorik. Die nicht-orthodoxe Seite stellte im Geiste des Realismus die Frage: Wie können Künstler oder Maler jemanden abbilden, den sie nie gesehen haben? Nikolaus von Dresden erhob den Vorwurf, dass die Heiligen auf den Bildern mit schönen Gesichtern nach dem Vorbild von Tänzern und Tänzerinnen dargestellt seien, wodurch bei den Gläubigen sündige Begierden geweckt werden können. Ihre Kleidung, ihre Verhaltensweisen und ihre Gesten werden nach dem Vorbild der Bräuche ihrer eigenen Umgebung abgebildet. Christus und die Apostel präsentieren sich in kunstvollen, kostbaren Gewändern, obwohl wir doch wissen, dass sie in Wirklichkeit arm waren. Die Künstler zeigen den hl. Petrus mit Bart und einer dreifachen goldenen Krone auf dem Kopf, ähnlich auch die Gottesmutter in herrlichen Gewändern. Die anthropomorphen Abbildungen der Heiligen Dreifaltigkeit bezeichnet er als Sünde, da Gottvater dort als ein alter Mann mit Bart dargestellt wird ${ }^{110}$. Er verwarf das solchen Bildern angeblich gebührende Lob und machte sich auf diese Weise über das von Wünschelburg angeführte Argument der ikonischen Metaphorik lustig. Wenn die Bilder zu Recht lehren sollten wie die Schrift („gentibus pro leccione et eorum scriptura est pictura"), dann sind solche Künstler Sünder, ja Fälscher - schrieb der hussitische Theologe Nikolaus von Dresden ${ }^{111}$.

Die wenig bekannte Schrift Wünschelburgs ist eines der interessantesten Beispiele für die gegen die hussitische Ikonophobie gerichtete Polemik eines orthodoxen Theologen, der sicher aus persönlichen Beweggründen, in Erinnerung an den hussitischen Überfall auf seine Heimatstadt in Schlesien, seinen eigenen Kampf gegen die Widersacher

109 „Concedo bene, quod nullus vivens debet adorare ymaginem propter seipsam, sed crucifixum debet adorari propter passionem Cristi in ipso depictam et reductam per hoc in hominis memoriam“, Nicolai de Dresda „De imaginibus“, S. 220.

110 Nicolai de Dresda „De imaginibus“, S. 227; Nechutová, Traktát Mikuláše z Dráždan, S. 152.

111 Nicolai de Dresda „De imaginibus“, S. 225. 
im Glauben führte und diesen dann wahrscheinlich im pastoralen Bereich lange Jahre hindurch als aktiver Prediger auf der Kanzel in Amberg umsetzte. Ob es eine Art Antwort sei, der zunehmenden Angst sowie Empörung folgend, auf die nach 1419 in Böhmen erheblich aufgehäuften Angriffe auf Kirchen und die massenweise fortschreitende Bildzerstörung durch die versammelte Menschenmenge, dann schließlich auf die Debatte in Basel, bleibt nur als reine Vermutung offen. Jedenfalls betrachtet man in letzter Zeit in der wissenschaftlichen Forschung, ganz im Gegensatz und sogar im Abweichen von theoretischer, lehrsamer Bildfeindlichkeit (Ikonophobie), dafür eher mehr dem praktischen Ikonoklasmus zugewandt, diese Entwicklung der böhmischen Bildstürmerei als fast revolutionären Kampf um Symbole, Gesten sowie Gedenken (Bilder als Medium fürs Andenken im erinnerungspolitischen Kontext) und im Endeffekt ums Austauschen von der Gemeinschaftssymbolik der alten infrage gestellten Kultur und deren Anhänger durch neue Hussitenzeichen ${ }^{112}$. Es steht fest, dass der Verfasser schlesischer Herkunft eine solche Tätigkeit im heimatlichen Schlesien übertraf, was übrigens ein bisschen später, im Jahre 1453, von einem italienischen Franziskaner Mönch Johannes Capistranus in die Wege geleitet wurde. Damit hat sich Wünschelburg der antihussitischen Agitation gegen Ikonophobie angeschlossen ${ }^{113}$. Die von Capistranus in seinen Predigten während seines Aufenthalts in Schlesien sowie in Mitteleuropa angesprochenen Motive der Passionsfrömmigkeit samt Verehrung des leidenden Christi, Compassio der Mutter Gottes

112 Bartlová, Der Bildersturm, S. 33, 39-40; dies., Pravda zvítězila, S. 63, 95.

113 A. Lissowska, Antyhusycka misja Jana Kapistrana na Śląsku, in: Bernardyni na Śląsku w późnym średniowieczu, hg. v. J. Kostowski, (2005), S. 60-61; J. Kostowski, "Contra hereticos hussitas“. O niektórych aspektach stylu pieknego na Śląsku i w krajach sąsiednich, „Biuletyn Histori Sztuki“, 60, 3-4 (1998), S. 572-576; ders. Sztuka śląska wobec husytyzmu. Późnogotyckie świadectwa malarskie, „Artium Quaestiones“, 5 (1991), S. 29-59; ders., Die Kunst der Spätgotok und der Hussitismus. Einige Forschungsprobleme, in: The Bohemian Reformation and Religious Practice, hg. v. Z. V. David, D. R. Holeton, 5 (2004), S. 267-284; M. Kapustka, Figura i hostia. O obrazowym przywoływaniu obecności w późnym średniowieczu, (2008), S. 269-285. 
(Marienklage) und des Namens Jesu mit seinem visuellen Attribut Triagramm IHS stimmen mit Wünschelburgs Verteidigung der obigen Bildmotive im Rahmen der iniitierten Rückkehr zu dem sog. schönen Stil, doch von Hussiten sogar ausgelacht, überein. Diese Angelegenheit bedarf jedoch gesonderter Studien zur gesamten unerforschten Hinterlassenschaft des Johannes von Wünschelburg, besonders was sein Predigtschaffen betrifft, worunter wir nicht nur die in dieser bayrischen Stadt, sondern auch an den Universitäten in Prag und in Leipzig gehaltenen Predigten verstehen ${ }^{114}$.

Übersetzt von

Herbert Ulrich

\section{ANNEX \\ JOHANNES DE WÜNSCHELBURG (DE RADKÓW) TRACTATUS DE SUPERSTITIONIBUS}

(INCIPIT UND EXPLICIT)

1. Incipt: „Tempus putationis advenit“, scribitur Canticum secundo capitulo $[2,12]$. Philaretus in tractatu De natura morborum dicit, quod in medicina rite congrueque summenda motum siderum seu stellarum aspicere, oportet quia dicit Aristoteles secundo De generatione, quod motus solis et aliorum planetarum in aliquo circulo, hoc est zodaico, est causa generationis et corruptionis rerum in hiis inferioribus. ... $><\ldots$ Explicit: „Septimo expense faciende per viam eundo stando in Roma et redeundo ad partes sex alia opera commutet pietatis. Octavo iniungat sibi iuxta fidele videri suum tot ecclesias, quas in penitentia XXX diebus singulis et singulas continuis vel interpellatis fideliter visitet. Nono, quod promittat eidem fideliter, quod si alia puncta contineat bulla, quod illa fideliter adimplebit sine fraude et cetera"115.

114 Siehe weiter Anm. 20.

115 Nach der Handschrift aus der BUWr., Sign. I F. 212. 


\section{Verzeichnis der Handschriften des Traktats}

Biblioteka Uniwersytecka we Wrocławiu (BUWr.):

- Sign. I F. 212, f. 228ra-258vb - Prov.: Bibliothek des Doms von St. Jakob zu Neisse (Nysa) (ecclesiae collegiatae),

- Sign. I F. 274, f. 229r-258r - Prov.: Bibliothek des Augustiner-Chorherrenstiftes zu Sagan (Żagań),

- Sign. I Q. 384, f. 40r-102r - Prov.: Bibliothek des Augustiner-Chorherrenstiftes zu Sagan (Żagań), Augustiner-Propstei Grünberg (Zielona Góra),

- Sign. 6098 (Mil.II.46), f. 419ra-446rb - Prov.: Universität Leipzig (Lipsk); Görlitz (Zgorzelec).

Sächsische Landesbibliothek - Staats- und Universitätsbibliothek Dresden (LSUB Dresden):

- Sign. Mscr. Dresd. P. 104, f. 1ra-38vb - Prov.: Franziskanerkloster in Meissen (Miśnia).

Gymnasialbibliothek Magdeburg:

- Sign. 113, f. 350v-377r - Prov.: Gymnasialbibliothek, Erfurt (?), Magdeburg (Kriegsverlust).

\section{Traktatsinhalt}

Introductio, Hs. BUWr. Sign. I F. 212, f. 228ra-233rb (LSUB Dresden Sign. P. 104, f. 1ra-8ra; BUWr. Sign. I F. 274, f. 229ra-234rb; BUWr. Sign. 6098 (Mil. II 46), f. 419ra-423vb; BUWr. Sign. I Q. 84, f. 40r-51v).

[1] De superstitiositate verborum, Hs. BUWr Sign. I. F. 212, f. 233rb-236vb (LSUB Dresden Sign. P. 104, f. 8ra-13ra; BUWr. Sign. I. F. 274, f. 234rb-237vb; BUWr. Sign. 6098, f. 423vb-427rb; BUWr. Sign. I. Q. 384, f. 51v-59r).

[2] De superstitiositate temporis, Hs. BUWr Sign. I. F. 212, f. 236vb-239rb (LSUB Dresden Sign. P. 104, f. 13ra-16rb; BUWr. Sign. I F. 274, f. 237vb-240ra; BUWr. Sign. 6098, f. 427rb-429va; BUWr. Sign. I F. 384, f. 59r-63v).

[3] De ymaginibus et signis eorum, Hs. BUWr. Sign. I F. 212, f. 239rb-245ra (LSUB Dresden Sign. P. 104, f.16rb-22vb; BUWr. Sign. I F. 274, f. 240ra-245ra; BUWr. Sign. 6098, f. 429va-434ra; BUWr. Sign. I Q. 384, f. 63v-74v).

[4] De ymaginibus sanctorum, quibus utitur Ecclesia et cruce crucifixi, Hs. BUWr. Sign. I F. 212, f. 245ra-248rb (LSUB Dresden Sign. P. 104, f. 22vb-27rb; BUWr. Sign. I F. 274, f. 245ra-248rb; BUWr. Sign. 6098, f. 434ra-437ra; BUWr. Sign. I Q. 384, f. $74 \mathrm{v}-81 \mathrm{r}$ ).

[5] De miraculis circa ymagines, Hs. BUWr. Sign. I F. 212, f. 248va-250ra (LSUB Dresden Sign. P. 104, f. 27rb-29ra; BUWr. Sign. I F. 274, f. 248rb-250ra; BUWr. Sign. 6098, f. 437ra-437va; BUWr. Sign. I Q. 384, f. 81r-84v). 
[6] De miraculis Christi, Hs. BUWr. Sign. I F. 212, f. 250ra-258vb (Dresden Sign. P. 104, f. 29ra-38vb; BUWr. Sign. I F. 274, f. 250ra-258ra; BUWr. Sign. 6098, f. 437va-445va; BUWr. Sign. I Q. 384, f. 84v-102r).

\section{POLEMIKA Z HUSYCKIM \\ IKONOKLAZMEM W ŚWIETLE TRAKTATU DE SUPERSTITIONIBUS JANA Z WÜNSCHELBURGA († CA. 1456)}

\section{(STRESZCZENIE)}

W artykule zostały przedstawione poglądy Jana z Wünschelburga (obecnie Radków k. Kłodzka) (1380/1385-ok. 1456), wykształconego w Pradze teologa pochodzenia śląskiego. Ten aktywny na uniwersytecie w Lipsku oraz w Ambergu (Bawaria) wykładowca i kaznodzieja wypowiadał się na temat prawowierności, negatywnych zjawisk towarzyszących kultowi obrazów i wizerunków świętych, fałszywych cudów oraz pielgrzymek w kontekście krytyki husyckiego ikonoklazmu. Podstawowym źródełem dla zawartych w artykule rozważań stał się mało znany, zachowany jedynie w pięciu rękopisach z drugiej połowy XV wieku traktat De superstitionibus, w szczególnosci jego najważniejsza dla podjętego tematu część zatytułowana De ymaginibus et signis eorum, w której zawarta została krytyka husyckiego obrazoburstwa.

\section{POLEMIK GEGEN DEN HUSSITISCHEN BILDERSTURM IM LICHTE DES TRAKTATES DE SUPERSTITIONIBUS DES JOHANNES VON WÜNSCHELBURG († CA. 1456)}

\section{(ZUSAMMENFASSUNG)}

Der Artikel stellt die Ansichten von Johannes von Wünschelburg (heute Radków bei Kłodzko) (1380/1385-ca. 1456) dar, einen in Prag ausgebildeten Theologen schlesischer Herkunft. Der an der Universität Leipzig und in der bayerischen Stadt Amberg aktive Theologe und Prediger setzte sich mit der Orthodoxie, den negativen Tendenzen bei der Verehrung von Heiligenbildern sowie mit falschen Wundern und Pilgerreisen im Zusammenhang mit der Kritik am hussitischen Ikonoklasmus auseinander. Als primäre Quelle für die in dem vorliegenden Artikel beschriebenen Überlegungen wurde ein wenig bekannter, nur in fünf Handschriften aus der zweiten Hälfte des 15. Jahrhunderts erhaltener Traktat De superstitionibus herangezogen, insbesondere der 
für das Thema entscheidende Teil unter dem Titel De ymaginibus et signis eorum, in dem die Kritik am hussitischen Ikonoklasmus am Fundiertesten zum Ausdruck kommt.

Übersetzt von

Renata Skowrońska

\section{THE POLEMICS WITH HUSSITE ICONOCLASM IN THE LIGHT OF THE TREATISE DE SUPERSTITIONIBUS BY JOHANNES OF WÜNSCHELBURG († CA. 1456)}

\section{(SUMMARY)}

The article presents the views of Johann of Wünschelburg (now Radków near Kłodzko) (1380/1385 - c. 1456), a man of Silesian origin who was educated in Prague. As a theologian and preacher working at the university in Leipzig and Amberg (Bavaria), he spoke about orthodoxy, negative phenomena connected with the worship of religious pictures and images of the saints, fake miracles and pilgrimages in the context of the criticism of Hussite iconoclasm. The basic source for the speculations included in the article was the unfamiliar De superstitionibus treatise, preserved in only five manuscripts from the $15^{\text {th }}$ century, the most significant part of which was titled De ymaginibus et signis eorum and included the criticism of Hussite iconoclasm.

Translated by Agnieszka Chabros

\section{Słowa kluczowe / Schlagworte / Keywords}

- Ikonoklazm; husytyzm; przesądy; Jan z Wünschelburga (Radków)

- Ikonoklasmus; Hussitismus; Aberglauben; Johann von Wünschelburg (Radków)

- Iconoclasm, the Hussites, superstitions, Johannes of Wünschelburg (Radków) 


\section{BIBLIOGRAFIA / BIBLIOGRAFIE / BIBLIOGRAPHY}

\section{ŹRÓDŁA ARCHIWALNE / ARCHIVALISCHE QUELLEN / ARCHIVAL SOURCES}

Bayerische Staatsbibliothek in München: Johannes de Wünschelburg, Discipulum de sanctis ac officiarium de sanctis, Sign. Clm 9730, f. 161r-236v.

Universitätsbibliothek Würzburg: Johannes de Wünschelburg, Sermones Quadragesimas, Sign. M. ch. f. 137, f. 99va-131rb.

Biblioteka Uniwersytecka we Wrocławiu:

- Johannes de Wünschelburg, De superstitionibus, Sign. I F. 212, f. 228ra-258vb, Sign. I F. 274, f. 229ra-258ra; Sign. 6098 (Mil. II 46), f. 419ra-446rb; Sign. I Q. 384, f. $40 \mathrm{r}-102 \mathrm{r}$.

- Johannes de Wünschelburg, Sermo defunctorum magistri Johanni Wunschelburgensis, Sign. I. Q. 58, f. 110vb-113ra.

- Nikolaus Magni de Jauer/Jawor, De superstitionibus, Sign. I F. 313, f. 255ra-282vb. Sächsische Landesbibliothek- Staats- und Universitätsbibliothek Dresden: Johannes de Wünschelburg, De superstitionibus, Sign. P. 104, f. 1ra-38vb.

Magdeburg Gymnasialbibliothek, Johannes de Wünschelburg, De superstitionibus, Sign. 113, f. 350v-377 r. (Kriegsverlust).

Archiwum Archidiecezjalne i Biblioteka Kapitulna we Wrocławiu: Revocatio et refutatio articulorum Wernheri de Fridburgo, Sign. 309, f. 75va-79rb.

\section{ŹRÓDłA DRUKOWANE / GEDRUCKTE QUELLEN / PRINTED SOURCES}

Acta capitulorum nec non iudiciorum ecclesiasticorum selecta, hg. v. B. Ulanowski, 2 (1902).

Augustinus, De Trinitate, hg. v. J.-P. Migne, (Patrologia Latina 42, 1843), col. 819-1098. Augustinus, In Joannis Evangelium. Tractatus XL, hg. v. J.-P. Migne, (Patrologia Latina 35, 1864), col. 1379-1976.

Augustinus, Sermo 198. De kalendis Januariis, hg. v. J.-P. Migne, (Patrologia Latina 38, 1845), col. 1024-1026.

Chronik des Martin von Bolkenhain, hg. v. F. Wachter, in: Geschichtschreiber Schlesiens des XV. Jahrhunderts, hg. v. ders., (Scriptores rerum silesiacarum 12, 1883), S. $1-18$.

Concilium Pisanum 1409, hg. v. J. Miethke, in: Conciliorum oecumenicorum generaliumque decreta. Editio critica, 2: The General Councils of Latin Christendom, 1: From Constantinople IV to Pavia Siena (869-1424), hg. v. A. Melloni et al., (Corpus Christianorum 2013), S. 471-658. 
Cronica monasterii canonicorum regularium (S. Augustini) in Glacz = Kronika klasztoru kanoników regularnych (św. Augustyna) w Kłodzku, hg. v. W. Mrozowicz, (2003).

Das älteste Glatzer Stadtbuch, 1324-1412, hg. v. Fr. Volkmer, W. Hohaus, (Geschichtsquellen der Graffschaft Glatz 4, 1889).

Der Urkundenbuch der Universität Leipzig von 1409 bis 1555, hg. v. B. Stübel, (Codex diplomaticus Saxoniae regiae 2, 11, 1879).

Die Matrikel der Universität Leipzig, hg. v. G. Erler, 1-2 (Codex diplomaticus Saxoniae regiae 2, 16 und 17, 1895 und 1897).

Dokumenty soborów powszechnych, 3: Konstancja Bazylea - Ferrara - Florencja Rzym (1414-1445), hg. v. A. Baron, H. Pietras, (2004).

Epitome bibliothecae Conradi Gesneri, apud Christophorum Froschouerum, mense Martio, anno 1555 Content, Drucker: Tigvuri (1555).

Friedrich Zarncke, Die urkundlichen Quellen zur Geschichte der Universität Leipzig in den ersten 150 Jahren ihres Bestehens, „Abhandlungen der philologisch-historischen Klasse der Königlichen Sächsischen Gesellschaft der Wissenschaften“, 3 (1857), S. 509-922.

Georgii Fabricii Chemnicensis Rerum Misnicarum libri VI, Lib. 2, Drucker: Cvrante Ernesto Voegelino (1569).

Gilles Charlier, Aegidi Carlerii Liber de legationibus Basiliensis pro reductione Bohemorum, hg. v. E. Birk, (Monumenta conciliorum generalium seculi decimi quinti. Concilium Basileense. Scriptorum 1, 1857), S. 359-700.

Gregorius I Magnus, Epistola CV. Ad Serenum Massiliensem Episcopum, hg. v. J.-P. Migne, (Patrologia Latina 77, 1849), col. 1027-1028.

Guilielmi Alverni episcopi parisiensis De fide et legibus, in: William of Auvergne, Opera Omnia, Venetiis. Ex Officina Damiani Zenari (1591).

Henry Charles Lea, Materials Toward a History of Witchcraft, 1 (1938).

Hugon Ripelin de Argentina, Compendium theologicae veritatis, in: Albertus Magnus, B. Alberti Magni Ratisbonensis episcopi, Ordinis Praedicatorum, opera omnia [...], hg. v. A. Borgnet, 34 (1895), S. 1-261.

Ivan Sojkovič, Johannis de Ragusio Tractatus, quomodo Bohemi reducti sunt ad unitatem ecclesiae, hg. v. F. Palacký, (Monumenta Conciliorum Generalium seculi decimi quinti. Concilium Basileense. Scriptorum 1, 1857), S. 133-286.

Ivan Stojkovič, Initium et prosecutio Basiliensis concili, hg. v. F. Palacký, (Monumenta conciliorum generalium seculi decimi quinti. Concilium Basileense. Scriptorum 1, 1857), S. 1-131.

Jean Damascène, La Foi orthodoxe, 2: 45-100, hg. v. B. Kotter, (Sources chretiennes 540, 2011). 
Johannes Damascenus, Contra imaginum calumniatores I-III, in: S. Joannis Damasceni De imaginibus oratio I-III. Adversus eos, qui sacras imagines abiiciunt, hg. v. J.-P. Migne, (Patrologia Graeca 94, 1867), col. 1231-1420.

Johannes Damascenus, De fide orthodoxa, hg. v. J.-P. Migne, (Patrologia Graeca 94, 1867), col. 790-1228.

Johannes Gerson, Quaedam argumentatio adversus eos, qui publice volunt dogmatizare seu praedicare populo, quod si quis audit missam, in illo die non erit caecus nec morietur morte subitanea et talia multa, in: ders., Opera Omnia, hg. v. L. E. Du Pin, 2 (1706).

Johannes Hus, Expositio Decalogi, in: Spisy M. Jana Husi, hg. v. V. Flajšhans, (Sbirka pramenů českého hnutí náboženského ve XIV. a XV. století 1, 1903).

Johannes Hus, Super quattuor Sententiarum, 1-3, in: Spisy M. Jana Husi, hg. v. V. Flajšhans, (Sbírka pramenů českého hnutí náboženského ve XIV. a XV. století 4-6, 1904-1906).

Johannes von Frankfurt, Questio, utrum potestas cohercendi demones fieri possit per caracteres, figuras atque verborum prolationes, in: J. Hansen, Quellen und Untersuchungen zur Geschichte des Hexenwahns und der Hexenverfolgung im Mittelalter, (1901), S. 71-82.

Johannis Wyclif Sermones, hg. v. J. Loserth, 1-4 (Wyclif's Latin Works 11-14, 1887-1890).

Joseph Hansen, Quellen und Untersuchungen zur Geschichte des Hexenwahns und der Hexenverfolgung im Mittelalter, (1901).

Joseph Klapper, Erzählungen des Mittelalters in deutscher Übersetzung und lateinischen Urtext, (1914).

Liber decanorum facultatis philosophicae universitatis Pragensis ab anno Christi 1367 usque ad annum 1585, 1 (Monumenta Historica Universitatis Carolo-Ferdinandae Pragensis 1, 1830).

Matthiae de Janov dicti magister Parisiensis Regulae veteris et novi testamenti, Liber III: Tractus de Anticristo. Accedit tractatus magistrorum Parisiensium de periculis novissiorum temporum rec non Milicii libellus de antichristo, hg. v. V. Kybal, (1911).

Matthiae de Janov dicti Magistri Parisiensis Regularum veteris et novi testamenti, Liber V: De corpore Christi, hg. v. J. Nechutová, H. Krmíčková, (Veröffentlichungen des Collegium Carolinum 69, 6 1993).

Peter von Žatca, Petri Zatecensis Liber diurnus de gestis Bohemorum in concilio Basileensi, hg. v. F. Palacký, (Monumenta conciliorum generalium seculi decimi quinti. Concilium Basileense. Scriptorum 1, 1, 1857), S. 287-357.

Practica maister Hannsens von Wunschlwurg, hg. v. F. Lauchert, Materialien zur Ge- 
schichte der Kaiserprophetie im Mittelalter, 1: Die dem Johannes Wünschelburg zugeschriebene Prophezeiung, „Historisches Jahrbuch der Görres-Gesellschaft“, 4 (1898), S. 850-851.

Pražské synody a koncily předhusitské doby, hg. v. J. V. Polc, Z. Hlediková, (2002).

Repertorium Germanicum. Verzeichnis der in den päpstlichen Registern und Kameralakten vorkommenden Personen, Kirchen und Orte des Deutschen Reiches, seiner Diözesen und Territorien vom Beginn des Schismas bis zur Reformation, 4: Verzeichnis der in den Registern und Kameralakten Martins V. vorkommenden Personen, Kirchen und Orte des Deutschen Reiches, seiner Diözesen und Territorien, 1417-1431, hg. v. K. A. Fink, 3 (1957).

Stanisław ze Skarbimierza, Sermo 47, in: Stanisław ze Skarbimierza, Sermones sapientiales, hg. v. B. Chmielowska, (Textus et Studia Historiam Theologiae in Polonia Excultae Spectantia 4, 2, 1979), S. 82-94.

Synody diecezji wrocławskiej $i$ ich statuty, hg. v. J. Sawicki, (Concilia Poloniae. Źródła $i$ studia krytyczne 10, 1963).

Thesaurus de la littérature interdite au XVI siècle, Auteurs, ouvrages, éditions, hg. v. J. M. de Bujanda, (Index des livres interdits 10, 1996).

Thomas de Aquino, Summa theologiae, II.II, in: Sancti Thomae Aquinatis Opera omnia iussu impensaque Leonis XIII P.M. edita, 9 (1897).

Tomas von Haselbach, De decem praeceptis, hg. v. A. E. Schönbach, Zeugnisse zur deutschen Volkskunde des Mittelalters, „Zeitschrift des Vereins für Volkskunde“, 12, 1 (1902), S. 1-14.

Urkunden und Regesten zur Geschichte der Graffschaft Glatz von 1401 bis 1500, hg. v Fr. Volkmer, W. Hohaus, (Geschichtsquellen der Graffschaft Glatz 2, 1888).

\section{LITERATURA / LITERATUR / LITERATURE}

Albert F., Die Husiten vor Glatz, in: Die Hussitennot im Glatzer Lande. Gedenkblätter zum Fünfhundertjahrtag des Gefechts am Roten Berge, hg. v. Fr. Albert, (Glatzer Heimatschriften 20,1928), S. 48-54.

Bach A., Urkundliche Kirchengeschichte der Grafschaft Glaz: Von der Urzeit bis auf unsere Tage, (1841).

Bailey M. D., Fearful Spirits, Reasoned Follies. The Boundaries of Superstition in Late Medieval Europe, (2013).

Bartkiewicz K., Dzieje Ziemi Kłodzkiej w wiekach średnich, (Monografie Ślaskie Ossolineum 28, 1977).

Bartlová M., Pravda zvitězila. Výtvarné umění a husitství 1380-1490, (2015), S. 53-98. 
Bartlová M., Bildersturm der böhmischen Hussiten. Ein neuer Blick auf eine radikale mittelalterliche Geste, „Wiener Jahrbuch für Kunstgeschichte“, 59 (2010), S. 27-48.

Bartlová M., Obraz jako náboženský problém. Husitské obrazoborectví, in: Umění české reformace (1380-1620), ed. K. Horníčková, M. Šroněk, (2011), S. 41-204.

Bartlová M., Skutečná prítomnost: středověký obraz mezi ikonou a virtuální realitou, (2012).

Bartlová M., Understanding Hussite Iconoclasm, „Filosofický časopis AV ČR“, Suppl. 1 (2009), S. 115-126.

Bartoš F. M., Posláni M. Ondřeje Gałky králi Vladislavu Varnenčíkovi, „Věstník Královské české společnosti nauk, trrida fil.-hist..", 1 (1934), S. 1-36.

Bělohlávková J., Die Ansichten über Bilder im Werk tschechischen Reformprediger, „Studie o rukopisech“, 29 (1992), S. 53-64.

Bělohlávková J., Jakoubek ze Stříbra a Petr Payne: O obrazech, (1987).

Boockmann H., Der Streit um das Wilsnacker Blut. Zur Situation des deutschen Klerus in der Mitte des 15. Jahrhunderts, ,Zeitschrift für historische Forschung“, 9 (1982), S. 385-408.

Bracha K., "Cristus in siner jogent vnd kintheit gewundert hart". IX-ty punkt oskarżenia brata Wernera $z$ Friedbergu w procesie $z 1405$ r., in: Inkwizycja papieska w Europie Środkowo-wschodniej, hg. v. P. Kras, (2010), S. 329-348.

Bracha K., „De ymaginibus sanctorum, quibus utitur ecclesia et cruce“ $w$ traktacie De superstitionibus (1444/1445) Jana $z$ Wünschelburga, in: Peregrinationes. Pielgrzymki w kulturze dawnej Europy, hg. v. H. Manikowska, H. Zaremska, (Colloquia Mediaevalia Varsoviensia 2, 1995), S. 64-71.

Bracha K., „Semen est verbum Dei“. Postylla Carcer animae przypisywana Janowi Szczeknie, in: Amoenitates vel lepores philologiae, hg. v. R. Laskowski, R. Mazurkiewicz, (2007), S. 61-71.

Bracha K., Des Teufels Lug und Trug. Nikolaus Magni von Jauer: Ein Reformtheologe des Spätmittelalters gegen Aberglaube und Götzendienst, (Quellen und Forschungen zur Europäischen Ethnologie 25, 2013).

Bracha K., Errores augustianina - eremity Wernera z Friedbergu w świetle inkwizycji heidelberskiej z 1405 roku, in: Klasztor w społeczeństwie średniowiecznym i nowożytnym, hg. v. M. Derwich, A. Pobóg-Lenartowicz, (1996), S. 471-481.

Bracha K., Mierzenie nicią i ważenie ciał. O pewnej praktyce wotywnej w średniowieczu, in: Cursus mille annorum. Prace ofiarowane Profesorowi Eugeniuszowi Wiśniowskiemu, hg. v. A. Kuźma, P. Plisiecki, L. Poniewozik, „Roczniki Humanistyczne“, 47, 2 (2000), S. 61-72.

Bracha K., Zwischen miracula, mirabilia und mira. Die Wallfahrten nach Wilsnack im Urteil Jakobs von Paradies, in: Die Wilsnackfahrt. Ein Wallfahrts- und Kommuni- 
kationszentrum Nord- und Mitteleuropas im Spätmittelalter, hg. v. F. Escher, H. Kühne, (Europäische Wallfahrtsstudien 2, 2006), S. 165-177.

Bretholz B., Der Ursprung der Husitenkriege und ihr Uebergreifen auf die Grafschatz Glatz, „Glatzer Hematblätter“, 14 (1928), S. 122-131.

Bretschneider P., Die Hussiten in Wünschelburg, in: Die Hussitennot im Glatzer Lande. Gedenkblätter zum Fünfhundertjahrtag des Gefechts am Roten Berge, hg. v. Fr. Albert, (Glatzer Heimatschriften 20, 1928), S. 39-42.

Bünz E., Die Leipziger Universitätsgründung - eine Folge des Kuttenberger Dekret, in: Universitäten, Landesherren und Landeskirchen: Das Kuttenberger Dekret von 1409 im Kontext der Epoche von der Gründung der Karlsuniversität 1348 bis zum Augsburger Religionsfrieden 1555, hg. v. B. Zilynská, (Historia Universitatis Carolinae Pragensis 49, 2, 2010), S. 55-64.

Bünz E., Rudersdorf M., Döring D., Geschichte der Universitat Leipzig 1409-2009, 1: Spätes Mittelalter und Frühe Neuzeit 1409-1830/31, (2009).

Burkhart P., Die lateinischen und deutschen Handschriften der Universitätsbibliothek Leipzig, 2, 5: Die lat. und dt. Hs.. Die theologischen Handschriften, 1: (Ms 501-625), (1999).

Bylina S., Podróż husytów do Bazylei, (2013).

Bylina S., Rewolucja husycka, 2: Czas chwały i czas zmierzchu, (2015).

Bylina S., Rewolucja husycka. Przedświt i pierwsze lata, (2011).

Bylina S., Wplywy Konrada Waldhausena na ziemiach polskich $w$ drugiej połowie XIV i pierwszej połowie XV wieku, (1966).

Bylina S., Z problematyki kontaktów Macieja $z$ Janowa ze Ślaskiem $w$ drugiej połowie XIV wieku, „Śląski Kwartalnik Historyczny Sobótka“, 19, 3-4 (1964), S. 328-335.

Cetwiński M., Pradzieje i średniowiecze, in: Kłodzko. Dzieje miasta, hg. v. R. Gładkiewicz, (1998), S. 33-56.

Chlíbec J., K vývoji názorů Jana Rokycany na umělecké dílo, „Husitský Tábor“, 8 (1985), S. 39-57.

Dębicki J., Ein Beitrag zur Bildertheologie der vorhussitischen und hussitischen Zeiten in Böhmen, „Uměni', 30, 6 (1992), S. 415-422.

Dębicki J., Ideowe przesłanki obrazoburstwa w Czechach w czasach przedhusyckich i husyckich a teologia obrazu w okresie wczesnej reformacji, in: Sztuka i dialog wyznań w XVI i XVI wieku, hg. v. J. Harasimowicz, (2000), S. 77-87.

Demm E., Zur Rolle des Wunders in der Heiligkeitskonzeption des Mittelalters, „Archiv für Kulturgeschichte“, 57 (1975), S. 300-344.

Die Handschriften der Universitätsbibliothek Würzburg, 2: Die Handschriften aus benediktinischen Provenienzen, bearb. v. H. Thurn, 1 (1973). 
Dobschütz E. von, Christusbilder. Untersuchungen zur christlichen Legende, (Texte und Untersuchungen zur Geschichte der altchristlichen Literatur 18, NF., 3, 1899).

Dola K., Problemy kościelno-duszpasterskie w diecezji wrocławskiej w XV wieku, „Śląski Kwartalnik Historyczny Sobótka“, 41, 4 (1986), S. 517-537.

Donckel E., Studien über die Prophezeiung des Fr. Telesforus von Cosienza, O.F.M. 1365-1386, „Archivum Franciscanum Historicum“, 26 (1933), S. 29-104, $282-314$.

Eis G., Keil G., Nachträge zum Verfasserlexikon, „Studia Neophilologica“, 31 (1959), S. 242.

Fijałek J., Mistrz Jakub z Paradyża i uniwersytet krakowski w okresie soboru bazylejskiego, 1 (1900).

Flajšhans V., Pražšti theologove kolem r. 1400, „Časopis Českého musea“, 76-77 (1905-1906), S. 16-31.

Franz A., Die kirchlichen Benediktionen im Mittelalter, 2 (1909).

Franz A., Die Messe im deutschen Mittelalter, (1902).

Franz A., Mathias von Liegnitz und Nicolaus Stör von Schweidnitz, „Der Katholik. Zeitschrift für katholische Wissenschaft und kirchliche Leben“, 17, 78 (1898), S. 1-25. Fuchs F., Buchbesitz als Altersvorsorge. Eine Bibliothekstiftung des Johann von Wünschelburg für die Prädikatur bei St. Martin in Amberg im Jahre 1450, in: Wirtschaft - Gesellschaft - Mentalitäten im Mittelalter, hg. v. H.-P. Baum, R. Leng, J. Schneider, (Beiträge zur Wirtschafts- und Sozialgeschichte 107, 2006), S. 683-695.

Gersdorf E., Die Universität Leipzig im ersten Jahre ihres Bestehens, „Bericht an die Mitglieder der Deutschen Gesellschaft zur Erforschung Vaterländischer Sprache und Alterthümer", (1847), S. 1-61.

Grabski A. F., Polska w opiniach Europy Zachodniej, (1968).

Grünhagen C., Die Hussitenkämpfe der Schlesier 1420-1435, (1872).

Halama O., Otázka svatých v české reformaci, (2002).

Halm K., Laubmann G. von, Meyer W., Catalogus codicum latinorum Bibliothecae Regiae Monacensis, 2, 1: Codices num. 8101-10930 complectens und 2, 4: Codices num. 21406-27268 complectens, $(1874,1881)$.

Harmening D., Wörterbuch des Aberglaubens, (2005).

Helssig R., Die lateinischen und deutschen Handschriften der Universitätsbibliothek Leipzig, 1: Die theologischen Handschriften, 1: (Ms 1-500), (unveränderter Nachdruck der Auflage von 1926, 1995).

Helssig R., Die lateinischen und deutschen Handschriften der Universitätsbibliothek Leipzig, 3: Die juristischen Handschriften, (unveränderter Nachdruck der Auflage von 1905, 1996).

Hermann E., Veniet aquila de cuius Molatu delebitur Leo. Zur Gamaleon-Predigt des 
Johann von Wünschelburg, in: Festiva lanx. Studien zum mittelalterlichen Geistesleben Johannes Spörl dargebracht aus Anlass seines sechzigsten Geburtstages, hg. v. K. Schnith, (1966), S. 95-117.

Herold V., Mraz M., Zur Geschichte des tschechischen philosophischen Denkens der vorhussitischen Zeit (Stand, Probleme und Perspektiven der Forschung), „,Mediaevalia Philosophica Polonorum", 24 (1979), S. 21-55.

Herschel A., Dr. Wünschelburg, „Serapeum“, 15 (1854), S. 331-333.

Hertel G., Abergläubische Gebräuche aus dem Mittellalter, „Zeitschrift des Vereins für Volkskunde", 11 (1901), S. 272-279.

Herzig A., Ruchniewicz M., Dzieje Ziemi Kłodzkiej, (2006).

Honemann V., ,Wilsnacker Wunderblut', in: Die deutsche Literatur des Mittelalters. Verfasserlexikon, 10 (1999), Sp. 1171-1178.

Hoyer S., Der Altag in einer Universität de 15. Jahrhunderts. Magister und Scholaren der Alma Mater Lipsienisis, in: Mentalität und Gesellschaft im Mittelalter, hg. v. S. Tanz, (1993), S. 237-260.

Hoyer S., Die Gerichtsbarkeit der Universität Leipzig bis zum Ende des 15. Jahrhunderts, in: Rechtsbücher und Rechtsordnungen in Mittelalter und früher Neuzeit, (Schriftenreihe des Sächsischen Staatsministeriums der Justiz 9, 1999), S. $122-142$.

Hoyer S., Die Gründung der Leipziger Universität und Probleme ihrer Frühgeschichte, in: Karl-Marx-Universität Leipzig, 1409-1959, (Beiträge zur Universitätsgeschichte 1, 1959), S. 1-34.

Hoyer S., Die Gründung einer Universität in Leipzig 1409, „Leipzig. Aus Vergangenheit und Gegenwart. Beiträge zur Stadtgeschichte", 3 (1984), S. 77-93.

Hoyer S., Die scholastische Universität bis 1480, in: Alma mater Lipsiensis. Geschichte der Karl-Marx-Universität Leipzig 1409-1959, hg. v. L. Rathmann, (1984), S. 9-32.

Hrdina J., Ośrodki pielgrzymkowe w średniowiecznych Czechach. Problematyka i realia, in: Peregrinationes w kulturze dawnej Europy, hg. v. H. Manikowska, H. Zaremska, (Colloquia Mediaevalia Varsoviensia 2, 1995), S. 252-260.

Jażdżewski K., Catalogus manu scriptorum codicum medii aevi latinorum signa 180-260 comprehendens, (1982).

Kapustka M., Figura i hostia. O obrazowym przywoływaniu obecności w późnym średniowieczu, (2008).

Kejř J., Česká otázka na Basilejském koncilu, „Husitský Tábor“, 8 (1985), S. 107-132. Kirn O., Die Leipziger Theologische Fakultät in fünf Jahrhunderten, in: Festschrift zur Feier des 500-Jährigen Bestehens der Universität Leipzig, 1 (1909). 
Klapper J., Deutsche Volksglaube in Schlesien in ältester Zeit, „,Mitteilungen der schlesischen Gesellschaft für Volkskunde“, 17, 1 (1915), S. 19-57.

Knapiński G., Biblia pauperum. Rzecz o dialogu słowa i obrazu, „Nauka“, 4 (2004), S. $133-164$.

Kostowski J., „Contra hereticos hussitas”. O niektórych aspektach stylu pięknego na Ślasku $i$ w krajach sąsiednich, „Biuletyn Historii Sztuki“, 60, 3-4 (1998), S. 572-576.

Kostowski J., Die Kunst der Spätgotok und der Hussitismus. Einige Forschungsprobleme, in: The Bohemian Reformation and Religious Practice, 5, 2, ed. Z. V. David, D. R. Holeton, (2004), S. 267-284.

Kostowski J., Sztuka śląka wobec husytyzmu. Późnogotyckie świadectwa malarskie, „Artium Quaestiones“, 5 (1991), S. 29-59.

Kracik J., Święte obrazy wśród grzesznych sarmatów. Ze studium nad recepcją kultowego dziedzictwa, „Nasza Przeszłośćc, 76 (1991), S. 141-192.

Krása J., Husitské obrazoborectví: poznámky k jeho studiu,„Husitský Tábor“, 8 (1985), S. 9-17.

Krause K., Alma mater Lipsiensis. Geschichte der Universität Leipzig von 1409 bis zur Gegenwart, (2003).

Krchňák A., Čechové na Basilejském sněmu, (1997).

Kretzenbacher L., Kreuzholzlegenden zwischen Byzanz und dem Abendlande. Byzantinisch-griechische Kreuzholzlegenden vor und um Basileios Herakleios und ihr Fortleben im lateinischen Westen bis zum Zweiten Vaticanum, (Sitzungsberichte der Bayerische Akademie der Wissenschaften 3, 1995), S. 1-74.

Kurze D., Johann von Wünschelburg, in: Die deutsche Literatur des Mittelalters. Verfasserlexikon, 4 (21983), Sp. 818-822.

Kusche B., „Ego collegiatus“ - die Magisterkollegien an der Universität Leipzig von 1409 bis zur Einführung der Reformation 1539. Eine Struktur- und personengeschichtliche Untersuchung, 2 (2009).

Kybal V., M. Matej z Janova. Jeho život, spisy a učeni, (1905).

Lauchert F., Wünschelburg, in: Algemeine Deutsche Biographie, 44 (1898), Sp. 320-321.

Lerner R. E., Werner di Friedberg intrappolato dalla legge, in: La parola all'accusato, hg. v. J.-C. Maire Vigueur, A. Paravicini Bagliani, (1991), S. 268-281.

Lincke U., Die Einfälle der Husiten in die Grafschaft Glatz und das Gefecht am Roten Berge, ,Glatzer Heimatblätter“, 14 (1928), S. 150-155.

Lissowska A., Antyhusycka misja Jana Kapistrana na Śląsku, in: Bernardyni na Śląsku w późnym średniowieczu, hg. v. J. Kostowski, (2005), S. 51-63.

Machilek F., Die Schlesier an der Universität Prag vor 1409, „Archiv für Schlesiche Kirchengeschichte“, 32 (1974), S. 81-102. 
Machilek F., Ludolf von Sagan und seine Stellung in der Auseinandersetzung um Konziliarismus und Hussitismus, (Wissenschaftliche Materialien und Beiträge zur Geschichte und Landeskunde der böhmischen Länder 8), (1967).

Machilek F., Schlesien, Hus und die Hussiten 1403-1435, in: Die Hussitische Revolution. Religiöse, politische und regionale Aspekte, hg. v. F. Machilek, (2012), S. 109-141.

Maleczyńska E., Ruch husycki w Czechach i w Polsce, (1959).

Manikowska H., Ruch pielgrzymkowy na Śląsku w średniowieczu - problemy badawcze, in: Peregrinationes w kulturze dawnej Europy, hg. v. H. Manikowska, H. Zaremska, (Colloquia Mediaevalia Varsoviensia 2, 1995), S. 225-241.

Maniura R., Shepherd R., Introduction, in: Presence. The Inherence of the Prototype within Images and Other Objects, ed. R. Maniura, R. Shepherd, (2006), S. 1-30.

Marchal G. P., Das vieldeutige Heiligenbild. Bildersturm im Mittelalter, in: Macht und Ohnmacht der Bilder. Reformatorischer Bildersturm im Kontext der Europäischen Geschichte, „Historische Zeitschrift. Beihefte, New Series“, 33 (2002), S. 307-332.

Molnár A., Chebský soudce, in: Soudce smluvený v Chebu. Sborník př́íspěvkư přednesenych na symposium k 500. výročí, květen 1982 Cheb, (1984), S. 5-40.

Mrozowicz W., Konwent kłodzki i jego kultura w XV wieku w świetle własnej kroniki, in: Święty Stanisław Kazimierczyk CRL (1433-1489). Postać - środowisko kultura - dziedzictwo, hg. v. K. Łatak, (2010), S. 250-262.

Mrozowicz W., Kronika klasztoru kanoników regularnych $w$ Kłodzku. Ze studiów nad średniowiecznym dziejopisarstwem klasztornym, (2001).

Nechutová J., Filius patri mortuo statuam fecit. Bájný antický príběh v české reformaci, in: Jakoubek ze Stríbra. Texty a jejich pưsobení, hg. v. O. Halama, P. Soukup, (2006), S. 87-101.

Nechutová J., Nicolai de Dresda „De imaginibus“, „Sborník prací Filozofické Fakulty Brněnské univerzity. E: Řada archeologicko-klasická", 19, 15 (1970), S. 211-240.

Nechutová J., Polemika Štěpána s Dolan z husitskou ikonofobií, in: Hussitism - Reformation - Reinassance, hg. v. J. Pánek, M. Polívka, N. Rejchrtová, (1994), S. 391 399.

Nechutová J., Polemika Štěpána z Dolan z husitskou ikonofobií, in: Hussitism - Reformation - Reinassance, hg. v. J. Pánek, M. Polívka, N. Rejchrtová, (1994), S. 391-400.

Nechutová J., Prameny předhusitské a husitské ikonofóbie, „Husitský Tábor“, 8 (1985), S. 29-38.

Nechutová J., Traktát „De ymaginibus“, připisovaný Petru Paynovi (Pražský univerzitní kodex IX E 10, ff. 210v - 214r), „Husitský Tabor“, 9 (1987), S. 325-334. 
Nechutová J., Traktát Mikuláše z Dráždan „De imaginibus“ a jeho vztah k Matěji $z$ Janova, „Sborník prací Filozofické Fakulty Brněnské univerzity. E: Ǩada archeologicko-klasická", 13, 9 (1964), S. 149-162.

Neumann A., Die katholischen Märtyrer der Hussitenzeit, (1930).

Nikodem J., Od Brna do Iglawy. Husyckie misje dyplomatyczne z lat 1419-1436, „Kwartalnik Historyczny“, 121, 1 (2014), S. 107-132.

Nodl M., Dekret Kutnohorský, (2010).

Pietsch P., Kleine Beiträge zur Kenntnis des Aberglaubens des Mittelalters, „Zeitschrift für deutsche Philologie“, 16 (1884), S. 185-196.

Plank P., Staurotheka, in: Lexikon für Theologie und Kirche, 9 (2000), S. 941-942.

Potkowski E., Książka rękopiśmienna w kulturze Polski średniowiecznej,(1984).

Reifferscheid A., Neun Texte zur Geschichte der religiösen Aufklärung in Deutschland während der 14. und 15. Jahrhunderts, in: Festschrift der Universität Greifswald, (1905), S. 47-50.

Rejchrtová N., Obrazoborecké tendence utrakvistické mentality jagellonského období a jejich dosah, „Husitský Tábor“, 8 (1985), S. 59-68.

Repertorium der lateinischen Sermones des Mittelalters für die Zeit von 1350-1500, nach der Vorarbeit v. J. B. Schneyer hg. v. L. Hödl, W. Knoch, (CD ROM, 2001).

Roth F. W. E., Die Artikel Wernhers von Friedberg 1405, „Quartälblatter des historischen Vereins für Grossherzogtum Hessen“, 1 (1886), S. 42-46.

Royt J., Die Hussiten und ihr Verhältnis zur Kunst, in: Jan Hus - Zwischen Zeiten, Völkern, Konfessionen, hg.v. F. Seibt, Z. Dittrich, (Veröffentlichungen des Collegium Carolinum, 85), (1997), S. 314-315.

Sauser E., Die Verehrung des heiligen, lebenspendenden Kreuzes in der Ostkirche, „Trierer Theologische Zeitschrift", 112, 2 (2003), S. 85-89.

Schmidt J., Johannes von Wünschelburg, in: Festschrift zu Dr. Franz Volkmers 75 Geburstag, hg. v. A. Franz, (Glatzer Heimatschriften 5, 1921), (1921), S. 32-44.

Sedlačkova K., Jakoubek ze Střibra a tzv. tynske kazani z 31. ledna 1417. Nazory predhusitskych a husitskych 'reformatorů' na obrazy, „Opuscula historiae artium. Sbornik praci filosoficke fakulty brněnske university", F, 48 (2004), S. 7-43.

Seibt F., Johannes Hus und der Abzug der deutschen Studenten aus Prag 1409, in: ders., Hussitenstudien. Personen. Ereignisse. Ideen einer frühen Revolution, (Veröffentlichungen des Collegium Carolinum 60, ${ }^{2}$ 1991), S. 1-15.

Seibt F., Von Prag bis Rostock. Zur Gründung der Universitäten im Mitteleuropa, in: ders., Mittelalter und Gegenwart. Ausgewählte Aufsätze, hg. v. W. Eberhard, H.D. Heimann, (1987), S. 197-217.

Sesboüé B., Wolinski J., Bóg zbawienia, in: Historia dogmatów, hg. v. B. Sesboüé, 1 (1999). 
Šmahel F., Basilejská kompaktáta, jejich zpísemněnín a ratifikace, „Studia Mediaevalia Bohemica", 1, 2 (2009), S. 187-229.

Šmahel F., Basilejská kompaktáta. Př́běh deseti listin,(2011).

Šmahel F., Husitská revoluce, 3: Kronika válečných let, (1996).

Šmahel F., Pražske universitní studentstvo v předrevolučním období 1399-1419.

Statistikosociologická studie, (Rozpravy Československé Akademie Věd. Řada Společenských Věd 77, 3, 1967).

Šmahel F., Stärker als der Glaube: Magie, Aberglaube und Zauber in der Epoche des Hussitismus, „Bohemia. Zeitschrift für die Geschichte der böhmischen Länder“, 32, 2 (1992), S. 316-337.

Šmahel F., The Kuttenberg Decree and the Withdrawal of the German Students from Prague in 1409: A Discussion, in: ders., Die Präger Universität im Mittelalter. Gesammelte Aufsätze, (2007), S. 165-167.

Spunar P., Repertorium auctorum Bohemorum provectum idearum post Universitatem Pragensem conditam illustrans, (Studia Copernicana 25, 1985).

Stejskal K., Funkce obrazu v husitství, „Husitský Tábor“, 8 (1985), S. 19-28.

Stejskal K., Ikonoklasmus a naš pamatkovy fond, „Husitsky Tabor”, 13, (2002), S. $71-110$.

Stejskal K., Ikonoklasmus českého středověku a jeho limity, „Umění, 48 (2000), S. 206-217.

Stejskal K., Ještě k ikonoklasmu v Čechách,„Listy Filologické“, 122 (1999), S. 194-196. Stejskal K., Pokus o zničení obrazu v Betlémské kapli v Praze roku 1412. Př́spèvek k dějinám ikonoklasmu v Čechách, in: Septuaginta Paulo Spunar oblata (70+2), (2000), S. 399-400.

Stöllinger-Löser Ch., Johann von Wünschelburg [Korr./Nachtr.], in: Die deutsche Literatur des Mittelalters. Verfasserlexikon. Nachträge und Korrekturen, 11 (2002), Sp. 805-806.

Stöllinger-Löser Ch., Telesforus von Cosenza, in: Die deutsche Literatur des Mittelalters. Verfasserlexikon, 9 (1995), Sp. 679-682.

Theologische Realenzyklopädie, 6 (1980).

Tomek W. W., Děje University pražské, 1 (1849).

Třiška J.,Životopisný slovník předhusitské pražské univerzity 1348-1409, (Repertorium biographicum universitatis Pragensis praehussiticae 1981).

Ward B., Miracles and the Medieval Mind. Theory, Record and Event 1000-1215, (1987).

Weckwerth A., Der Name „Biblia pauperum“, „Zeitschrift für Theologie und Kirchengeschichte", 83 (1972), S. 1-33. 
Wesche M., Concilium Basileense, (abrufbar im Internet: http://www.repfont.badw. de/Concilium\%20Basileense.pdf).

Wessel K., Acheiropoietos, in: Reallexikon der byzantinischen Kunst, 1 (1966), S. 22-28.

Witkowska A., Zagadnienie mentalności religijnej w świetle „miracula“ $z$ XII/XIV w., in: Kościół w Polsce, 1: Średniowiecze, hg. v. J. Kłoczowski, (1966), S. 585-630.

Wostry W., Die Schlesier an der Universität Prag vor 1409, „Zeitschrift des Vereins für Geschichte Schlesien“, 66 (1932), S. 1-33.

Wróbel J., Aus der aktuellen Forschung über die mittelalterlichen Handschriften der Universitätsbibliothek in Leipzig, ,Studia Mediewistyczne“, 27, 1 (1990), S. 81-88. Wunder - Wallfahrt - Widersacher. Die Wilsnackfahrt, hg. v. H. Kühne, A.-K. Ziesak, (2005). 
